\title{
Heterosis and Combining Abilities in a Diverse Seven-Parent Pearl Millet Population Diallel Tested in West Africa
}

\section{Sonali Dutta}

University of Hohenheim: Universitat Hohenheim

Felix T. Sattler

University of Hohenheim: Universitat Hohenheim

Anna Pucher

University of Hohenheim: Universitat Hohenheim

Drabo Inoussa

INERA: Institut de l'Environnement et de Recherches Agricoles

Ahmad Issaka

Institut National de Recherche pour l'Agriculture l'Alimentation et l'Environnement

\section{Ousmane Sy}

Institut Sénégalais de Recherches Agricoles: Institut Senegalais de Recherches Agricoles

Moussa D. Sanogo

Institute of rural economy

Ignatius I. Angarawai

ICRISAT: International Crops Research Institute for the Semi-Arid Tropics

Bettina IG Haussmann ( $\sim$ bettina.haussmann@uni-hohenheim.de )

University of Hohenheim https://orcid.org/0000-0002-2360-6799

\section{Research Article}

Keywords: Combining ability, Gene action, Heterosis, Heterotic groups, Pearl millet, Yield stability

Posted Date: February 24th, 2021

DOl: https://doi.org/10.21203/rs.3.rs-232609/v1

License: (c) (1) This work is licensed under a Creative Commons Attribution 4.0 International License. Read Full License

Version of Record: A version of this preprint was published at Euphytica on November 15th, 2021. See the published version at https://doi.org/10.1007/s10681-021-02939-0. 



\title{
Heterosis and combining abilities in a diverse seven-parent pearl millet population diallel tested in West Africa
}

\author{
Sonali Dutta • Felix T. Sattler • Anna Pucher • Inoussa Drabo• Ahmad Issaka • \\ Ousmane Sy • Moussa D. Sanogo • Ignatius I. Angarawai • Bettina I.G. Haussmann
}

S. Dutta • F.T. Sattler • A. Pucher • B.I.G. Haussmann $(\bowtie)$

Institute of Plant Breeding, Seed Science and Population Genetics, University of Hohenheim, Stuttgart, Germany

e-mail: bettina.haussmann@uni-hohenheim.de

I. Drabo

Institute of the Environment and Agricultural Research (INERA), 01 BP 476 Ouagadougou, Burkina Faso

\author{
A. Issaka \\ National Institute of Agricultural Research \\ (INRAN), BP429 Niamey, Niger \\ O. Sy \\ Senegalese Institute for Agricultural Research \\ (ISRA), BP53 Bambey, Senegal \\ M. D. Sanogo \\ Institute of Rural Economy (IER), BP 262 Bamako, \\ Mali

\section{I. Angarawai} \\ International Crops Research Institute for the Semi- \\ arid Tropics (ICRISAT), PMB 3491, Kano, Nigeria \\ (Former address: Lake Chad Research Institute \\ (LCRI), Maiduguri, Nigeria).
}




\begin{abstract}
Pearl millet [Pennisetum glaucum (L.) R. Br.] is an important food-security crop to smallholder farmers in West Africa (WA). Breeding for high yield and stability is a major challenge in the harsh environments of WA but could be tackled by hybrid breeding. Knowledge of combining ability patterns and quantitative-genetic parameters is required for an efficient development of hybrid varieties. Hence, our objectives were to estimate the combining ability of seven genetically diverse Sahelian pearl millet populations from Senegal, Mali, Benin, Burkina Faso, Niger, Sudan and Nigeria and the heterosis and stability of their 42 diallel-derived population hybrids to inform pearl millet hybrid breeding. The genotypes were evaluated in six environments in WA in 2007. Grain yield (GY) exhibited an average panmictic mid-parent heterosis (PMPH) of 24\%, ranging from $-1.51 \%$ to 64.69\%. General combining ability (GCA) was significant across test environments as reflected by high heritability estimates and high GCA:SCA variance ratios. Thus, early selection for parental per se performance would be rewarding. The parental population from Sudan (IP8679) had strongly negative GCA for GY. Its lack of adaptation contributed to the predominance of additive effects in the present germplasm set. Parental populations PE02987 (Senegal), PE05344 (Mali) and ICMV IS 92222 (Niger) showed large positive GCA for GY. Their offspring, especially PE02987 × PE05344 and Kapelga $\times$ ICMV IS 92222, exhibited a high and stable GY across all test environments. Tapping the regional pearl millet genetic diversity seems therefore beneficial for hybrid breeding to increase pearl millet productivity in WA.
\end{abstract}

Keywords Combining ability $\bullet$ Gene action $\bullet$ Heterosis $\bullet$ Heterotic groups $\bullet$ Pearl millet $\bullet$ Yield stability 


\section{Introduction}

Pearl millet [Pennisetum glaucum (L.)] is one of the most important cereal crops in arid and semi-arid regions of Africa and India, due to its ability to tolerate severe abiotic stress such as drought, high temperature, poor soil conditions and salinity (Gemenet et al. 2015, Gemenet et al. 2016; Krishnamurthy et al. 2007; Payne et al. 1998; Pucher et al. 2015; van Staveren and Stoop 1985). It is mainly produced by African and Indian smallholder farmers as their major source of food along with its usage as green biomass (Kanfany et al. 2018) and building material (Mason et al. 2015). As it can serve both human and animal nutrition, pearl millet is often used as "dual purpose" crop (Kelley et al. 1996) in those countries. In addition, it is used as forage and cover crop in some regions of the United States, South America, and Australia (Bashir 2015). Pearl millet is a diploid crosspollinated crop, which can profit from the heterosis effect of hybrids (Pandey et al. 2015; Pucher et al. 2016; Sattler et al. 2019; Sattler and Haussmann 2020). Its protogynous type of flowering where the stigmas emerge earlier than the anthers and remain receptive for pollination for 3-4 days (Brunken 1977) increases the rate of outcrossing to $>70 \%$ (Bashir 2015, Burton 1974). The protogynous flowering together with drought tolerance, high seed numbers, good tillering ability, high heterosis and a low seeding rate make it suitable for population hybrid breeding in drought-prone regions (Bashir 2015).

Pearl millet yields are much lower in West Africa (WA) than in India. Grain yields in Niger and Senegal were on average $471 \mathrm{~kg} \mathrm{ha}^{-1}$ and $694 \mathrm{~kg} \mathrm{ha}^{-1}$ between 2010 and 2014, respectively. In contrast, India had an average pearl millet yield of $1157 \mathrm{~kg} \mathrm{ha}^{-1}$ over the same period (FAO 2017). In addition to the very harsh production conditions, a main reason behind this low grain yield in WA is the dependency on landraces for the production of pearl millet (Pucher et al. 2016). Furthermore, the adoption of improved open-pollinated varieties (OPVs) was very limited (Ndjeunga 1997; Smale et al. 2012) due to the lack of access to improved OPV seed along with their performance that did not always fulfill farmers' preferences (Bidinger et al. 2008). The adoption rate of improved varieties in WA countries, where local seed system development was implemented together with farmer-led seed cooperatives varies from 5\% to 37\% (Christinck et al. 2014). In contrast, this rate wavers around $65 \%$ to $70 \%$ in India (Kumara Charyulu et al. 2014).

Using hybrid cultivars combined with improved management practices has brought a tremendous yield increase in pearl millet in India from $305 \mathrm{~kg} \mathrm{ha}^{-1}$ in 1951-1955 to $1157 \mathrm{~kg} \mathrm{ha}^{-1}$ in 2010-2014 (Dave 1986; FAO 2017; Yadav and Rai 2013). However, hybrid seed production is more time consuming and cost intensive 
compared to OPVs and landraces. Therefore, a sufficiently large heterosis effect is required to cover the higher production costs (Duvick and Cassman 1999).

The heterosis effect of population hybrids (based on a cross between two open-pollinated populations) is termed panmictic mid-parent heterosis (PMPH). PMPH is the difference between the population hybrid and the mean of its two open-pollinated parents (Lamkey and Edwards 1999), while panmictic better-parent heterosis (PBPH) refers to the heterosis effect relative to the superior open-pollinated parent. Ouendeba et al. (1993) observed a 55\% higher average GY of crosses compared to their parents in a set of $10 \mathrm{WA}$ population hybrids. In comparison, Pucher et al. (2016) found a mean PMPH of 17\% in 100 factorial-derived WA population hybrids and Sattler et al. (2019) observed a mean PMPH of 23\% in 136 diallel-derived WA population hybrids. This indicates good scope for pearl millet hybrid breeding in Africa. Heterotic groups are genetically distinct germplasms groups, which upon crossing show high combining ability. Therefore, keeping those groups separately and not mixing them during the process of hybrid parent development is necessary (Melchinger and Gumber 1998). Significantly superior population hybrids can be developed from crossing genetically distinct WA OPVs, and farmers can regrow these hybrids where commercial seed sectors are scarce and underdeveloped (Pucher et al. 2016; Sattler et al. 2019; Sattler and Haussmann 2020).

Compared to single-cross hybrids, alternatives like 3-way, 4-way, top-cross or population hybrids could bring rewarding results in these stress-prone environments, due to their higher population buffering capacity (Haussmann et al. 2012). Single-cross hybrids are genetically uniform as they are developed from homozygous inbreed parents and do not express population buffering capacity (Haussmann et al. 2012). This uniformity makes the use of single cross hybrids risky for WA smallholder farmers as they do not have the means to counteract the multitude of biotic and abiotic stresses (Haussmann et al. 2012; van Oosterom et al. 1996; Weltzien et al. 1998;). Furthermore, producing single cross hybrids in WA requires a great effort on resource management, skilled labor and a viable seed industry (Kumara Charyulu et al. 2014). Therefore, single-cross hybrids are considered less appropriate for the extremely variable climate conditions that are prevalent in the Sahel (Sattler and Haussmann 2020).

Genetic diversity analysis in WA pearl millets revealed absence of genetically clearly distinct germplasm groups, rather a high admixture was found (Bashir et al. 2014; Pucher et al. 2015; Sattler et al. 2018; Stich et al. 2010). WA is the center of pearl millets' origin (Burgarella et al. 2018; Manning et al. 2011). In combination with the high outcrossing rate, variable planting dates, prolonged flowering growth stage of OPVs and landraces, and 
drought-tolerant wind-borne pollen (Haussmann et al. 2007; Hoekstra et al. 1989), this explains the observed high genetic admixture in WA. Consequently, this genetically admixed germplasm complicates the identification of putative heterotic groups in pearl millet using genomic tools (Pucher et al. 2016). However, Diack et al. (2017) were able to find distinct groups of early and late flowering genotypes in Senegalese pearl millet using twelve simple sequence repeat (SSR) markers. Additionally, grouping of distinct Indian pearl millet inbred seed (B) and pollinator $(\mathrm{R})$ lines was possible in more recent studies by using marker-assisted genetic distances, which may shed some light on the presence of putative heterotic gene pools in B and R lines (Ponnaiah et al. 2019, Ramya et al. 2018). Finally, Varshney et al. (2017) studied 345 cultivated and 31 wild accessions using 450,000 single nucleotide polymorphism (SNP) markers. They found an East, a Central and a West Sahel group, and a group of cultivated accessions that was closely related to the wild Central Sahelian accessions. Furthermore, they identified Indian $\mathrm{B}$ and $\mathrm{R}$ lines, whose offspring showed an $8 \%$ above average yield, with a genomic prediction approach. However, the best hybrids were partly derived from intra-group crosses, indicating a large genetic diversity within the B and the R group that could be explored. Pucher et al. 2016 found some high yielding hybrids from the crosses between Senegal $\times$ Niger or Senegal $\times$ Nigeria in an experiment of diallel cross with four pearl millet populations from five different WA countries. Sattler et al. 2019 also found good combining ability patterns between the OPVs from Niger and Senegal while crossing 17 pearl millet OPVs in diallel design. These studies yielded interesting results but were not able to propose distinct initial heterotic groups or patterns. However, the populations having higher GCA effects and per se performance could be allocated into eastern and western West and Central Africa to develop heterotic pools for successful hybrid breeding in pearl millet (Sattler and Haussmann 2020). Therefore, it is crucial to expand existing results with further factorial or diallel mating design-based yield trials to validate combining ability patterns between groups of genotypes across multiple locations and years.

The objectives of this study were: i) to determine heterosis effects in pearl millet population hybrids derived from geographically and phenotypically highly diverse Sahelian parental populations; ii) to validate and augment information about combining ability patterns among Sahelian pearl millets; iii) to study G×E interaction and stability of pearl millet population hybrids for GY and other agronomic traits; and iv) to complement existing recommendations for pearl millet hybrid breeding in WA. 


\section{Materials and Methods}

\section{Plant materials and experimental design}

Seven diverse early to medium maturity pearl millet parental populations (landraces or OPVs) from seven different Sahelian countries were selected from a pearl millet collection (Table 1). Selection was based on the complementarity of different agronomic traits and geographic origin. The control varieties were contributed from the following countries (Institutions): Nigeria (Lake Chad Research Institute, LCRI); Niger / Mali (International Crops Research Institute for the Semi-Arid Tropics - Sahelian Center, ICRISATSC / Institute of Rural Economy, IER); Niger (National Institute of Agricultural Research, INRAN); Mali (IER); Senegal (Senegalese Institute of Agricultural Research, ISRA).

Table 1 List of pearl millet parental populations and control varieties used in this study along with their country of origin, average panicle length, and average number of productive tillers.

\begin{tabular}{lllcc}
\hline Genotypes & Type & Country of origin & $\begin{array}{c}\text { Panicle length } \\
(\mathrm{cm})\end{array}$ & $\begin{array}{c}\text { Productive tillers } \\
\text { per plant (\#) }\end{array}$ \\
\hline PE02987 & Parent 1 & Senegal & 52 & 3 \\
PE05344 & Parent 2 & Mali & 30 & 5 \\
PE03942 & Parent 3 & Benin & 32 & 3 \\
Kapelga & Parent 4 & Burkina Faso & 26 & 5 \\
ICMV IS 92222 & Parent 5 & Niger & 53 & 3 \\
IP8679 & Parent 6 & Sudan & 26 & 5 \\
IP12182 & Parent 7 & Nigeria & 51 & 3 \\
Gwagwa & Control 1 & Nigeria & 25 & $*$ \\
Sosat C88 & Control 2 & Niger/Mali & 26 & 4 \\
CT6 & Control 3 & Niger & 48 & $*$ \\
Sadoré local & Control 4 & Niger & 55 & 2 \\
ICMV IS 89305 & Control 5 & Niger & 52 & 4 \\
Toroniou & Control 6 & Mali & 39 & 3 \\
Souna 3 & Control 7 & Senegal & 50 & 3 \\
\hline According to & Pata fran & & 4 \\
\hline
\end{tabular}

According to data from Pucher et al. 2015 or ICRISAT unpublished data. *data missing.

The populations were crossed in a 7×7 diallel mating design by following Griffing`s diallel method 3 (F1`s and reciprocals) to develop 42 population hybrids (Griffing 1956). The population crosses were created in the offseason 2006/07 at the ICRISAT station in Niger, using three planting dates and at least 15 panicles per parental population in each cross. All 42 population hybrids, their 7 parental populations, and 7 controls were evaluated in 2007 in six environments (locations) of WA (Table 2). The environments were Bambey (Senegal), Cinzana (Mali), Gampela (Burkina Faso), Maiduguri (Nigeria), Maradi (Niger) and Sadoré (Niger). There was variation among the test environments in terms of rainfall, soil type, temperature and geographical distribution (Table 2). 
At each experimental site, the seeds were sown by following a $7 \times 8$ alpha lattice design with three replications.

Each plot consisted of two rows of $4.8 \mathrm{~m}$ length with $0.75 \mathrm{~m}$ distance between them resulting in a plot size of 4.5 $\mathrm{m}^{2}$. 
Table 2 Information on the six experimental sites in West Africa.

\begin{tabular}{|c|c|c|c|c|c|c|c|}
\hline Site & Latitude & Longitude & Altitude (m) & Soil type & $\begin{array}{l}\text { Average annual } \\
\text { rainfall }(\mathrm{mm})\end{array}$ & $\begin{array}{l}\text { Temperature }\left({ }^{\circ} \mathrm{C}\right) \\
\text { in } 2007 \text { May- }\end{array}$ & $\begin{array}{c}\text { Rainfall (mm) in } \\
2007 \text { May- }\end{array}$ \\
\hline & & & & & & October & October \\
\hline Bambey (SN) & $14^{\circ} 43^{\prime} 12^{\prime \prime} \mathrm{N}$ & $16^{\circ} 36^{\prime} 41^{\prime \prime} \mathrm{W}$ & 23 & Sandy & 611 & 28 & 636 \\
\hline Cinzana (ML) & $13^{\circ} 14^{\prime} 60^{\prime \prime} \mathrm{N}$ & $-5^{\circ} 57^{\prime} 60^{\prime \prime} \mathrm{W}$ & 285 & Sandy loam & 630 & 32 & 301 \\
\hline Gampela (BF) & $12^{\circ} 25^{\prime} 51^{\prime \prime} \mathrm{N}$ & $1^{\circ} 22^{\prime} 18^{\prime \prime} \mathrm{W}$ & 275 & Sandy loam & 815 & 29 & 761 \\
\hline Maiduguri (NA) & $11^{\circ} 50^{\prime} 49^{\prime \prime} \mathrm{N}$ & $13^{\circ} 9^{\prime} 25^{\prime \prime} \mathrm{E}$ & 300 & Sandy & 621 & 27 & 1118 \\
\hline Maradi (NR) & $13^{\circ} 29^{\prime} 30^{\prime \prime} \mathrm{N}$ & $7^{\circ} 5^{\prime} 47^{\prime \prime} \mathrm{E}$ & 374 & Sandy & 560 & 32 & 228 \\
\hline Sadoré (NR) & $13^{\circ} 14^{\prime} 0^{\prime \prime} \mathrm{N}$ & $2^{\circ} 17^{\prime} 0^{\prime \prime} \mathrm{E}$ & 237 & Sandy & 556 & 32 & 215 \\
\hline
\end{tabular}

$\mathrm{SN}=$ Senegal, $\mathrm{ML}=$ Mali, $\mathrm{BF}=$ Burkina Faso, NA=Nigeria, $\mathrm{NR}=$ Niger.

Rainfall and temperature data sources: http://www.worldclimate.com/ and http://sdwebx.worldbank.org 
In each environment, except Gampela, seven hills were planted per row at an interval of $0.8 \mathrm{~m}$, having 14 hills per plot. In Gampela, each plot had 18 hills, 9 hills per row, as recommended by the Institute of the Environment and Agricultural Research (INERA). At all locations, thinning was done to two plants per hill at around three weeks after planting. Microdoses of $6 \mathrm{~g}$ 15N-15P-15K or $2 \mathrm{~g}$ DAP fertilizers per hill were applied at the time of seed sowing.

Phenotypic data were recorded on 13 agronomic traits: seedling vigor (SV; $5=$ excellent; $4=$ good; $3=$ medium, 2 = poor; 1 = very poor); percentage of downy mildew infested plants (DM\%); days to $50 \%$ flowering (FLO), measured from the time of sowing to the time when $50 \%$ of plant flowered in a plot; plant height (PH; $\mathrm{cm})$; panicle length $(\mathrm{PL} ; \mathrm{cm})$; panicle circumference $(\mathrm{CIR} ; \mathrm{cm})$; panicle compactness $(\mathrm{CMP} ; 3=$ excellent, 2=medium and 1=loose); number of productive panicles per hill (NPP); panicle yield (PY; $\mathrm{g} \mathrm{m}^{-2}$ ); grain yield $\left(\mathrm{GY} ; \mathrm{g} \mathrm{m}^{-2}\right.$ ); dry stover weight (STW; $\mathrm{g} \mathrm{m}^{-2}$ ); thousand seed weight (TSW; g); and volumetric weight of grains (VWG; $\mathrm{g} \mathrm{cm}^{-3}$ ). PH, CIR, and PL were measured on three representative plants per plot and then the average was calculated. Due to technical problems, VWG in Maiduguri and Maradi, DM\% in Maradi and TSW in Maiduguri were not recorded.

\section{Statistical analysis}

Raw data of each location were checked for outliers and tested for normality. The statistical analysis was performed following a one-step approach. Adjusted entry means were calculated based on the performance of the parents, controls, and hybrids using the following model across six environments:

$$
y_{i j k l}=\mu+g_{i}+e_{j}+(g \times e)_{i j}+r_{j k}+b_{j k l}+\varepsilon_{i j k l}
$$

where $y_{i j k l}$ is the observed phenotype; $\mu$ represents the general mean; $g_{i}$ refers to the effect of the $i$ th genotype; $e_{j}$ refers to the effect of the $j$ th environment; $(g \times e)_{i j}$ is the interaction effect between genotype $i$ and environment $j$; $r_{j k}$ is the effect of the $k$ th replication in the $j$ th environment; $b_{j k l}$ is the effect of $l$ th block nested in the $k$ th replication of $j$ th environment; and $\varepsilon_{i j k l}$ is the residual effect. For the estimation of entry means, the genotypic effects were considered fixed and all other effects were random. For the variance component estimation, all effects were regarded as random (Piepho et al. 2003). Broad-sense heritability $\left(H^{2}\right)$ for all 13 agronomic traits was calculated across environments, using the following formula,

$$
H^{2}=\sigma_{g}^{2} /\left(\sigma_{g}^{2}+\sigma_{g x e}^{2} / E+\sigma_{d}^{2} / E R\right)
$$


where $\sigma_{g}^{2}$ denotes genotypic variance component, $\sigma_{g x e}^{2}$ corresponds to genotype $\times$ environment interaction variance component, $E$ is the number of environments, $R$ is the number of replications and $\sigma_{\varepsilon}^{2}$ residual variance component. For single environment repeatability estimation, environment factors and interaction with the environment were discarded from the formula.

General (GCA) and specific combining ability (SCA) values, reciprocal effects (REC) as well as variance components for the GCA effect $\left(\sigma_{\text {gca }}^{2}\right), \operatorname{SCA}$ effect $\left(\sigma_{\text {sca }}^{2}\right), \operatorname{REC}$ effect $\left(\sigma_{\text {rec }}^{2}\right)$, GCA $\times$ environmental effect $\left(\sigma_{\text {gcaxE }}^{2}\right)$, SCA $\times$ environmental effect $\left(\sigma_{\text {scaxE }}^{2}\right)$ and reciprocal $\times$ environmental effect $\left(\sigma_{\text {rec } \times E}^{2}\right)$ were estimated using the following model (Griffing's method 3) in the software AGD-R developed by CIMMYT (Rodríguez et al. 2015).

$$
y_{i j k l m}=\mu+e_{k}+g c a_{i}+g c a_{j}+s c a_{i j}+r e c_{i j}+m_{i}+g c a_{i} * e_{k}+g c a_{j} * e_{k}+s c a_{i j} * e_{k}+r e c_{i j} * e_{k}+m_{i} * e_{k}+r_{k l}+b_{k l m}+
$$

where $y_{i j k l m}$ is the observed phenotype; $\mu$ is the general mean; $e_{k}$ refers to the effect of the $k$ th environment; $g c a_{i}$ and $g c a_{j}$ are the GCA effects of parents $i$ and $\mathrm{j}$, respectively; $s c a_{i j}$ is the SCA effect of parent combination $\mathrm{i}$ and $\mathrm{j}$; $r e c_{i j}$ is the reciprocal effect of parent combination $\mathrm{i}$ and $\mathrm{j} ; m_{i}$ is the maternal effect of female parent $\mathrm{i} ; g c a_{i} * e_{k}$ and $g c a_{j}{ }^{*} e_{k}$ are the GCA interaction effects from parents i and $\mathrm{j}$, respectively with environment k; $s c a_{i j}{ }^{*} e_{k}$ is the SCA interaction effect of parent combination $\mathrm{i}$ and $\mathrm{j}$ with environment $\mathrm{k}$; $\operatorname{rec}_{i j}{ }^{*} e_{k}$ is the reciprocal interaction effect of parent combination $\mathrm{i}$ and $\mathrm{j}$ with environment $\mathrm{k} ; m_{i} * e_{k}$ is the maternal interaction effect of female parent $\mathrm{i}$ with environment $\mathrm{k} ; r_{k l}$ is the effect of replication 1 in environment $\mathrm{k} ; b_{k l m}$ is the effect of incomplete block $\mathrm{m}$ nested in replication 1 in environment $\mathrm{k}$; and $\varepsilon_{i j k l m}$ is the residual error variance.

For variance component analysis, all the effects were treated as random except for the maternal effect.

PMPH and PBPH were estimated using the following formulas (Pucher et al. 2016):

$$
P M P H=[(H P-M P) / M P] \times 100 ; P B P H=[(H P-B P) / B P] \times 100
$$

where $\mathrm{HP}=$ hybrid performance, $\mathrm{MP}=$ mid-parent $((\mathrm{P} 1+\mathrm{P} 2) / 2)$ and $\mathrm{BP}=$ better parent (better performance according to the maximum value, but for FLO and DM\%, the minimum value is better). Standard heterosis (SH) was calculated relative to each control variety for GY using the following formula:

$$
S H=[(H P-C V) / C V] \times 100
$$

where $\mathrm{HP}=$ hybrid performance, and $\mathrm{CV}=$ performance of the control variety. Pearson's correlation coefficients were estimated among the agronomic traits in each environment separately and across environments using the adjusted entry means. Correlations coefficients were also computed between MP and HP; SCA and HP; per se 
performance of parental population and GCA, and PMPH and SCA. Geographic distances between parental populations' origins were calculated and correlation coefficients between geographic distance and hybrid performance, and geographic distance and PMPH were estimated. For stability analysis of genotypes across environments, the Additive Main Effects and Multiplicative Interaction Model (AMMI) was applied to calculate AMMI Stability Values (ASV; Purchase et al. 2000). Yield stability index (YSI) for each genotype was calculated using the ranking of overall mean performance and the raking of ASV (Farshadfar 2008; Mahmodi et al. 2011). YSI represent both GY performance and stability of the genotypes, with small scores indicating high stability combined with high GY. All calculations were computed within the R environment version 3.5.0 (R Development Core Team, 2018). Correlation coefficient and AMMI stability were analyzed using Agricolae package (de Mendiburu 2014). ASReml-R 3.0 (Butler et al. 2009) package was used for a single environment ANOVA and combined ANOVA.

\section{Results}

\section{Mean performance of genotypes at single environments and across environments}

Environmental means for GY (across parents, hybrids and controls) ranged from $252 \mathrm{~g} \mathrm{~m}^{-2}$ at Gampela, making it the best performing environment, to $43 \mathrm{~g} \mathrm{~m}^{-2}$ at Sadoré, which was the lowest performing environment (Supplemental Table 1). When combined across environments, mean GY ranged from 110 to $223 \mathrm{~g} \mathrm{~m}^{-2}$ for hybrids, from 96 to $188 \mathrm{~g} \mathrm{~m}^{-2}$ for parents and from 154 to $217 \mathrm{~g} \mathrm{~m}^{-2}$ for control varieties (Fig.1, Supplemental Table 2). The per se performance of parents 1,2 and 5 was higher than the marginal mean of all parents and they were considered high yielding out of 7 parents. Hybrid 22 (Kapelga $\times$ ICMV IS 92222) and hybrid 1 (PE02987 × PE05344) were the two best hybrids showing a mean GY of $223 \mathrm{~g} \mathrm{~m}^{-2}$ and $220 \mathrm{~g} \mathrm{~m}^{-2}$, respectively, which was greater than the best control variety ICMV IS $89305\left(217 \mathrm{~g} \mathrm{~m}^{-2}\right)$. These two hybrids were derived from intercountry crosses, namely Burkina Faso $\times$ Niger and Senegal $\times$ Mali. Wide ranges were observed within each entry group (parents, hybrids, checks) for most other traits, which can be observed from the boxplots below (Fig. 1). 

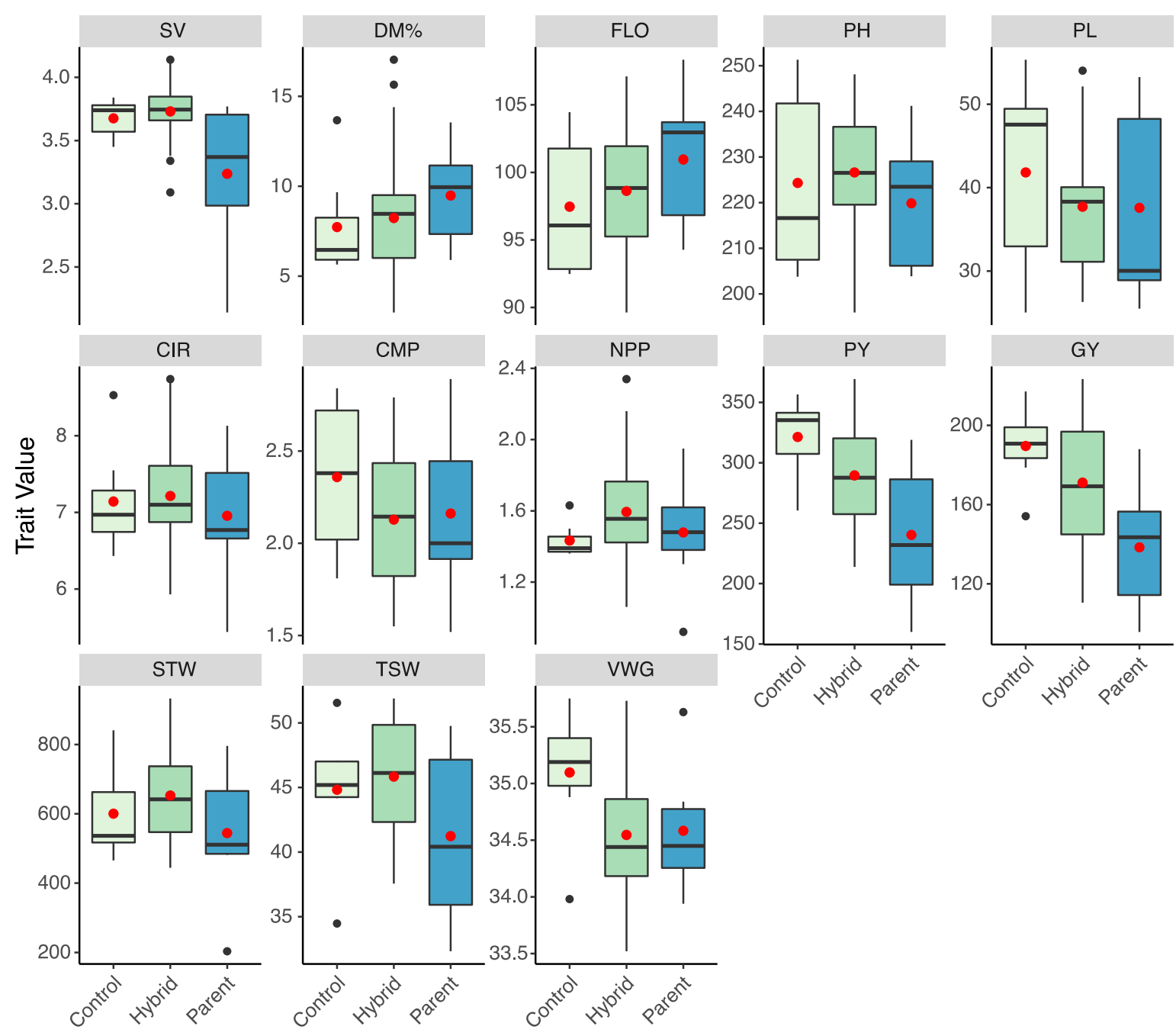

Genotype

Fig. 1 Boxplots with the arithmetic means (red dots) for 13 agronomic traits of 7 parental populations, their 42 offspring and 7 control varieties evaluated across six environments in West Africa. Traits are: SV, seedling vigor; DM\%, percentage of downy mildew infestations; FLO, days to 50\% flowering; PH, plant height; PL, panicle length CIR, panicle circumference, CMP, panicle compactness; NPP, number of panicles per plant; PY, panicle yield; GY, grain yield; STW; dry stover weight;; TSW, thousand seed weight; VWG, volumetric weight of grains.

\section{Estimates of heritabilities and variance components}

A wide range of heritability was observed for the 13 agronomic traits across the six environments. For single locations, the repeatability for GY ranged from 0.30 in Gampela to 0.82 in Bambey and Maradi, while combined across environments, GY showed a heritability of 0.60 (Table 3). The highest heritabilities were 
observed for PL (0.97) and FLO (0.94) across environments. DM\% showed a very low heritability of 0.03 . Estimates of $\sigma_{\text {gca }}^{2}$ were significant for most traits except for SV and DM\% (Table 3). Significant $\sigma_{\text {sca }}^{2}$ were observed for traits CIR, FLO, NPP, PH, TSW, VWG. $\sigma^{2}$ rec were only significant for NPP, PL, SV and TSW. The

$\sigma_{\text {gcaxE }}^{2}$ interaction variances were significant for most of the traits except for SV and DM\%. Significant $\sigma_{\text {scaxE }}^{2}$ and

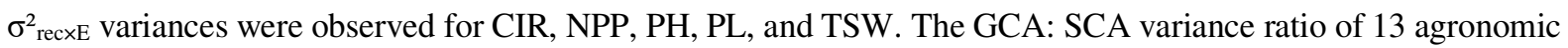
traits ranged from 0.21 for SV to 72.83 for PL, with all values larger than 1.0 indicating the preponderance of additive gene effects.

\section{Estimates of combining abilities across environments}

The GCA effects of the tested parents differed widely (Table 4). PE02987 was generally a good combiner for GY, PY, VWG, PL and CMP as it exhibited a significant positive GCA for these traits. Negative significant GCA effects for FLO exhibited by PE02987, PE03942 and ICMV IS 92222 are effective for breeding early flowering hybrids. Mixed results were observed for the SCA effects of hybrids across all traits (Supplemental Table 4). None of the hybrids was able to show consistent good SCA effects for all the traits. Hybrid 22 (Kapelga $\times$ ICMV IS 92222) showed the highest and significant positive SCA effect for GY, CMP, PY, and VWG. No significant SCA effects were observed for DM\%. REC effects were mostly non-significant for the observed traits.

\section{Estimates of heterosis and relationship among agronomic traits}

The hybrids showed an average PMPH of $23.70 \%$ for GY (Table 5). Almost 91\% of the hybrids showed a positive PMPH. While combined across environments, PMPH for GY ranged from $-3.47 \%$ for hybrid 29 (ICMV IS $92222 \times$ IP8679) to 64.69\% for hybrid 21 (Kapelga $\times$ PE03942) (Supplemental Table 5). For single environment analysis, the highest average PMPH was observed in Sadoré (68.80\%) followed by Bambey (56.35\%) (data not shown). For DM\%, an average negative PMPH (-10.09\%) was observed across environments (indicating better average resistance of hybrids). FLO exhibited an average negative PMPH (-2.33\%), which represents the earlier flowering of hybrids. The average PBPH for GY was $9.41 \%$ across environments, which ranged from $-27.14 \%$ to $62.10 \%$ (Table 5). $76 \%$ of the hybrids showed a positive PBPH for GY when combined across environments. Hybrid 9 (PE05344 × Kapelga) and hybrid 41 (IP12182 × ICMV IS 92222) were the most resistant and susceptible hybrids respectively as they showed the highest negative PBPH (-64.90\%) and positive PBPH for DM\% (152.42\%). The best average SH (19.18\%) was observed from hybrid 22 (Kapelga $\times$ ICMV IS 92222), which ranged from $2.87 \%$ for control 5 (ICMV IS 89305) to $44.88 \%$ for control 1 (Gwagwa) across the environments. 
The correlation coefficients between GY and yield component traits such as CIR, NPP and PL were ranging from -0.01 to 0.49 across environments (data not shown). $\mathrm{PH}$ had a significant positive correlation with GY ( $\mathrm{r}=0.30$ ). The significant negative correlation between DM\% and GY $(r=-0.29)$ indicated that the higher is the disease infestation, the higher is the yield loss. TSW was negatively correlated with CMP $(-0.32)$, while CMP was positively correlated with GY $(0.36)$.

\section{Relationship among quantitative-genetic parameters for different traits}

Correlations between MP and HP were significant for most of the traits except for SV and DM\% (Table 5). The highest correlation was recorded for PL ( $\mathrm{r}=0.97)$. Correspondingly, a highly significant positive correlation was observed between parental performance per se and GCA for most of the traits except for SV, DM\% and VWG. No significant association was observed between HP and SCA. Except for DM\% ( $\mathrm{r}=-0.31)$, no significant association was found between PMPH and SCA. Significant negative correlations were observed between geographic distances of parents' origins and HP for the traits PH, PY, GY, and TSW (Supplemental Fig.

1). Geographic distances and PMPH were also significantly negatively correlated with GY (Table 5 and Fig. 2). The non-adapted parent 6 from Sudan largely contributed to the negative relationship (Fig. 2). 


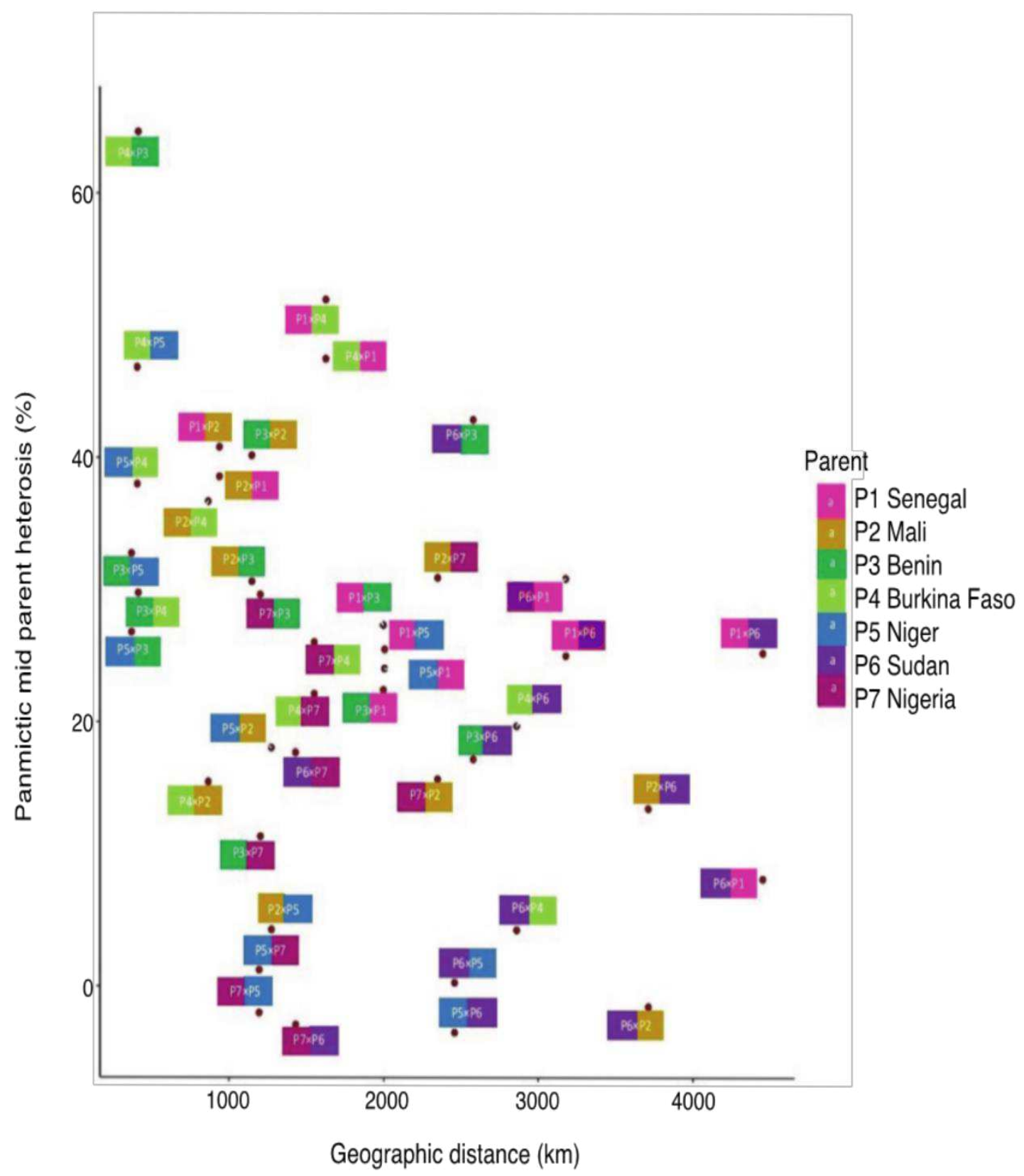

Fig. 2 Scatter plot showing relationship between geographic distances $(\mathrm{km})$ of parental populations' origins and panmictic mid parent heterosis for grain yield $\left(\mathrm{g} \mathrm{m}^{-2}\right)$ of 42 pearl millet population hybrids evaluated across six environments in West Africa. 
Table 3 Estimates of means, ranges, variance components, GCA: SCA variance ratios and heritabilities for 13 agronomic traits of 42 pearl millet population hybrids

evaluated across six environments in West Africa.

\begin{tabular}{|c|c|c|c|c|c|c|c|c|c|c|c|}
\hline \multirow[b]{2}{*}{ Traits $\dagger$} & \multirow[b]{2}{*}{ Means } & \multirow[b]{2}{*}{ Ranges } & \multicolumn{9}{|c|}{ Variance components } \\
\hline & & & $\sigma_{\text {gca }}^{2}$ & $\sigma_{\text {sca }}^{2}$ & $\sigma_{\text {rec }}^{2}$ & $\sigma_{\text {gca }}^{2}$ & $\sigma_{\text {scaxE }}^{2}$ & $\sigma_{\text {rec } \times \mathrm{E}}^{2}$ & $\sigma^{2}{ }_{e}$ & GCA: SCA & Heritability \\
\hline SV & 3.73 & $3.09-4.14$ & 0.01 & 0.01 & $0.01 *$ & 0.01 & 0.02 & $0.01 * *$ & 0.39 & 0.21 & 0.57 \\
\hline DM\% & 8.24 & $2.98-17.04$ & 1.09 & 0 & 1.05 & 14.35 & 0.01 & $0.01 * *$ & 77.26 & - & 0.03 \\
\hline FLO & 98.63 & 89.63-107.11 & $9.71 * *$ & $2.59 * *$ & 2.98 & $3.15 * *$ & $0.01 * *$ & 0.01 & 9.4 & 3.75 & 0.94 \\
\hline $\mathrm{PH}$ & 226.64 & $195.92-248.13$ & $109.91 * *$ & $15.50 * *$ & 8.31 & $17.29 * *$ & $0.01 * *$ & $12.79 * *$ & 364.6 & 7.09 & 0.86 \\
\hline PL & 37.71 & $26.29-54.02$ & $33.49 * *$ & 0.46 & $0.61 *$ & $0.46^{* *}$ & $0.07 * *$ & $0.75^{* *}$ & 23 & 72.83 & 0.97 \\
\hline CIR & 7.21 & $5.93-8.74$ & $0.26^{* *}$ & $0.02 * *$ & 0.01 & $0.05 * *$ & $0.01 * *$ & $0.01 *$ & 0.51 & 12.34 & 0.91 \\
\hline CMP & 2.13 & $1.55-2.79$ & $0.06 * *$ & 0.01 & 0 & $0.01 * *$ & $0.02 * *$ & 0.03 & 0.31 & 6.13 & 0.81 \\
\hline NPP & 1.59 & $1.06-2.34$ & $0.03 * *$ & $0.01 *$ & $0.01 * *$ & $0.02 * *$ & $0.01 * *$ & $0.00 * *$ & 0.21 & 4.61 & 0.76 \\
\hline PY & 289.5 & $213.80-369.23$ & $876.41 * *$ & 39.02 & 36.58 & $1062.42 * *$ & 972.75 & 59.64 & 5221.56 & 22.46 & 0.65 \\
\hline GY & 171.07 & $110.52-223.34$ & $412.24 * *$ & 35.6 & 2.12 & $675.67 * *$ & 517.07 & 132.39 & 2447.49 & 11.58 & 0.60 \\
\hline STW & 652.91 & $444.21-933.05$ & $9276.03 * *$ & 134.54 & 170.49 & $4004.39 * *$ & 2591.69 & 84.23 & 27208.88 & 68.95 & 0.84 \\
\hline TSW & 45.84 & $37.56-51.89$ & $4.89 *$ & $3.61 * *$ & $1.86^{* *}$ & $15.33 * *$ & $2.18^{* *}$ & $0.01 * *$ & 22.89 & 1.35 & 0.72 \\
\hline VWG & 34.55 & $33.52-35.73$ & $0.47 * *$ & $1.19 * *$ & 1.01 & $0.01 * *$ & 0.01 & 0.01 & 0.45 & 0.39 & 0.67 \\
\hline
\end{tabular}

$\uparrow$ Traits are: see Fig. 1

Significance levels are: * significant at $\mathrm{p}<0.05$ and $* *$ significant at $\mathrm{p}<0.01$, respectively. 
Table 4 General combining ability (GCA) effects of 7 pearl millet parental populations for 13 agronomic traits evaluated across six environments in West Africa.

\begin{tabular}{|c|c|c|c|c|c|c|c|c|}
\hline \multirow[b]{2}{*}{ Traits $\dagger$} & \multicolumn{8}{|c|}{ Parental populations } \\
\hline & $\begin{array}{c}\text { PE02987 } \\
\text { (P1, } \\
\text { Senegal) }\end{array}$ & $\begin{array}{c}\text { PE05344 } \\
\text { (P2, Mali) }\end{array}$ & $\begin{array}{c}\text { PE03942 } \\
\text { (P3, Benin) }\end{array}$ & $\begin{array}{c}\text { Kapelga } \\
\text { (P4, Burkina } \\
\text { Faso) }\end{array}$ & $\begin{array}{c}\text { ICMV IS } \\
92222(\text { P5, } \\
\text { Niger) }\end{array}$ & $\begin{array}{c}\text { IP8679 (P6, } \\
\text { Sudan) }\end{array}$ & $\begin{array}{c}\text { IP12182 } \\
\text { (P7, } \\
\text { Nigeria) }\end{array}$ & SE \\
\hline SV & -0.01 & 0.08 & 0.04 & -0.06 & $0.12 * *$ & $-0.09 *$ & -0.08 & 0.04 \\
\hline $\mathrm{DM} \%$ & -0.95 & $-2.44 * *$ & 1.20 & $-2.83 * *$ & 1.29 & $1.62 *$ & $2.12 * *$ & 0.66 \\
\hline FLO & $-2.90 * *$ & $2.24 * *$ & $-4.64 * *$ & $5.03 * *$ & $-1.51 * *$ & $1.36^{* *}$ & $0.43^{*}$ & 0.21 \\
\hline $\mathrm{PH}$ & $-9.06 * *$ & $7.74 * *$ & $-13.36 * *$ & $13.68^{* *}$ & 2.05 & $-10.38 * *$ & $9.33 * *$ & 1.30 \\
\hline PL & $5.38 * *$ & $-3.71 * *$ & $-5.14 * *$ & $-4.73 * *$ & $7.93 * *$ & $-4.77 * *$ & $5.06 * *$ & 0.33 \\
\hline CIR & $-0.14 * *$ & $0.31 * *$ & $0.96 * *$ & $-0.75^{* *}$ & $-0.14^{* *}$ & -0.03 & $-0.21 * *$ & 0.05 \\
\hline CMP & $0.25 * *$ & $-0.18 * *$ & $-0.32 * *$ & $0.20 * *$ & 0.06 & $-0.26^{* *}$ & $0.25 * *$ & 0.04 \\
\hline NPP & -0.02 & $0.20 * *$ & $-0.15^{* *}$ & $0.23 * *$ & $-0.14 * *$ & $0.14 * *$ & $-0.27 * *$ & 0.06 \\
\hline PY & $31.68 * *$ & $34.56 * *$ & $-21.96 * *$ & 4.44 & $26.63 * *$ & $-53.29 * *$ & $-22.06 * *$ & 4.95 \\
\hline GY & $22.54 * *$ & $13.16^{* *}$ & -5.22 & 4.78 & $20.79 * *$ & $-45.95 * *$ & -10.10 & 3.39 \\
\hline STW & $-53.28 * *$ & $122.47 * *$ & $-141.80 * *$ & $122.59 * *$ & $-44.98 * *$ & $53.34 * *$ & $-58.35 * *$ & 11.31 \\
\hline TSW & $-3.92 * *$ & $1.17 * *$ & $4.02 * *$ & $1.81 * *$ & $1.23 * *$ & $-3.97 * *$ & -0.34 & 0.36 \\
\hline VWG & $0.38 * *$ & $0.37 * *$ & $-0.16^{* *}$ & $-0.70^{* *}$ & $1.15^{* *}$ & $-1.19 * *$ & $0.14 *$ & 0.06 \\
\hline
\end{tabular}

$\uparrow$ Traits are: see Fig. 1

Significance levels are * significant at $\mathrm{p}<0.05$ and $* *$ significant at $\mathrm{p}<0.01$, respectively 
Table 5 Mean and ranges of panmictic mid-parent heterosis (PMPH) and panmictic better parent heterosis (PBPH); correlation between geographic distances of parental populations' origins and hybrid performance r(geodist, HP); geographic distances and PMPH r(geodist., PMPH); mid-parent and hybrid performance r(MP,HP); hybrid performance and SCA r(HP, SCA) of 42 population hybrids and parental populations per se performance and GCA r(per se, GCA) for 13 agronomic traits evaluated across six environments in West Africa.

\begin{tabular}{|c|c|c|c|c|c|c|c|c|c|c|}
\hline \multirow[b]{2}{*}{ Traits $\dagger$} & \multicolumn{10}{|c|}{ Parameters } \\
\hline & $\begin{array}{c}\text { PMPH } \\
\text { mean }\end{array}$ & $\begin{array}{l}\text { PMPH } \\
\text { ranges }\end{array}$ & $\begin{array}{c}\text { PBPH } \\
\text { mean }\end{array}$ & $\begin{array}{l}\mathrm{PBPH} \\
\text { ranges }\end{array}$ & r(geodist,HP) & r(geodist,PMPH) & $\mathrm{r}(\mathrm{MP}, \mathrm{HP})$ & $\mathrm{r}($ per se, GCA $)$ & $\mathrm{r}(\mathrm{HP}, \mathrm{SCA})$ & $\mathrm{r}(\mathrm{PMPH}, \mathrm{SCA})$ \\
\hline SV & 16.75 & -17.27 to 56.44 & 4.97 & -18.04 to 35.74 & -0.05 & $-0.31 *$ & -0.06 & -0.21 & 0.14 & -0.11 \\
\hline DM\% & -10.09 & -71.40 to 78.22 & 13.28 & -64.90 to 152.42 & 0.08 & 0.22 & 0.01 & -0.03 & -0.42 & $-0.31 *$ \\
\hline FLO & -2.33 & -7.09 to 1.61 & 0.80 & -4.93 to 8.73 & 0.00 & -0.27 & $0.91 * *$ & $0.93 * *$ & 0.02 & 0.01 \\
\hline PH & 3.03 & -4.63 to 9.58 & -0.85 & -8.75 to 7.34 & $-0.37 *$ & -0.29 & $0.85^{* *}$ & $0.91 * *$ & 0.05 & -0.01 \\
\hline PL & 0.53 & -9.97 to 10.14 & -13.55 & -28.46 to 4.50 & -0.04 & -0.08 & $0.97 * *$ & $0.99 * *$ & -0.03 & -0.18 \\
\hline CIR & 3.69 & -4.77 to 16.30 & -3.48 & -16.11 to 10.77 & -0.03 & -0.18 & $0.85 * *$ & $0.89 * *$ & 0.14 & 0.05 \\
\hline CMP & -1.49 & -22.70 to 26.81 & -12.36 & -40.14 to 18.78 & -0.09 & $-0.39 * *$ & $0.76^{* *}$ & $0.90 * *$ & -0.10 & -0.20 \\
\hline NPP & 7.82 & -13.23 to 30.25 & -4.25 & -28.38 to 22.67 & 0.14 & $0.33 *$ & $0.77 * *$ & $0.90 * *$ & -0.02 & -0.03 \\
\hline PY & 21.32 & -5.61 to 57.60 & 5.79 & -23.99 to 40.80 & $-0.32 *$ & $-0.32 *$ & $0.71 * *$ & $0.79 *$ & 0.03 & -0.09 \\
\hline GY & 23.70 & -3.47 to 64.69 & 9.41 & -27.14 to 62.10 & $-0.46^{* *}$ & $-0.38 * *$ & $0.71 * *$ & $0.79 *$ & 0.03 & -0.06 \\
\hline STW & 21.05 & -3.53 to 45.61 & 0.13 & -28.01 to 39.94 & 0.11 & $-0.34 *$ & $0.89 * *$ & $0.94 * *$ & -0.03 & -0.03 \\
\hline TSW & 11.55 & -0.65 to 31.99 & 1.37 & -17.80 to 23.39 & $-0.67 * *$ & -0.02 & $0.76^{* *}$ & $0.84 *$ & -0.06 & -0.10 \\
\hline VWG & -0.11 & -2.35 to 2.21 & -1.02 & -3.68 to 1.41 & -0.03 & -0.09 & $0.76 * *$ & 0.55 & -0.03 & -0.16 \\
\hline
\end{tabular}

$\dagger$ Traits are: see Fig. 1

Significance levels are * significant at $\mathrm{p}<0.05$ and $* *$ significant at $\mathrm{p}<0.01$, respectively 


\section{G $\times$ E interaction pattern and yield stability}

The AMMI biplots (Fig. 3 and Fig. 4) for GY illustrate G×E interaction patterns and stability of 42 hybrids, 7 parents and 7 control varieties across six environments. In the AMMI1 biplot (Fig. 3), genotypes which are situated on the right-hand side of the grand mean level and close to the line of $\mathrm{PC} 1=0$, are the high yielding and stable genotypes. Hybrids 22, 28 and 12 show above-average GY and high stability.

In Fig. 4 (AMMI2), PC1 and PC2 explained $52.5 \%$ and $18.3 \%$ of the total variation, respectively. The vectors of Gampela and Sadoré and, Maiduguri and Cinzana point at a similar direction and therefore, the G×E interaction between these environments was low. The vectors of Bambey and Maiduguri point at opposite directions in the AMMI2 biplot, which indicated the presence of high $\mathrm{G} \times \mathrm{E}$ interactions between them. Therefore, the ranking of genotypes based on GY among these environments was different. In the AMMI2 biplot, genotypes which were situated close to the center point $(\mathrm{PC} 1, \mathrm{PC} 2=0)$ are more stable than those, which were distant from the center point. For example, the position of hybrid $22(\mathrm{H} 22)$ fell close to the center point of the AMMI2 plot, therefore the performance of this genotype is highly stable across all six environments. ASV, showing the ranking of stability of the genotypes across environments, ranged from 1.11 to 14.27 , where lower ASV indicate more stable genotype and higher ASV indicates less stable genotypes (Supplemental Table 9). YSI ranged from 3 to 110 and hybrid 22 showed the least YSI followed by hybrids $12,14,21,8$ and 1. 


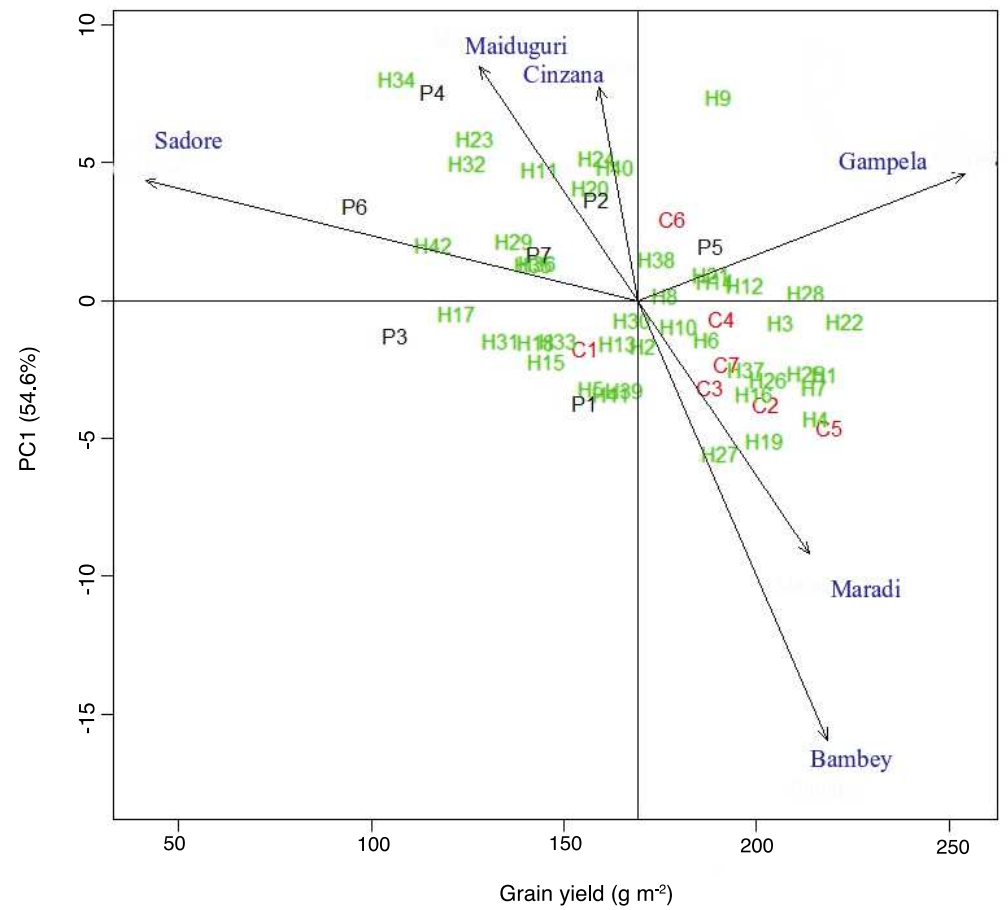

Fig. 3 AMMI1 biplot of grain yield $\left(\mathrm{g} \mathrm{m}^{-2}\right)$ vs. PC1 of 42 genotypes (7 parents (P, black), their 42 hybrids (H, green) and 7 controls (C, red)) evaluated across six environments in West Africa.

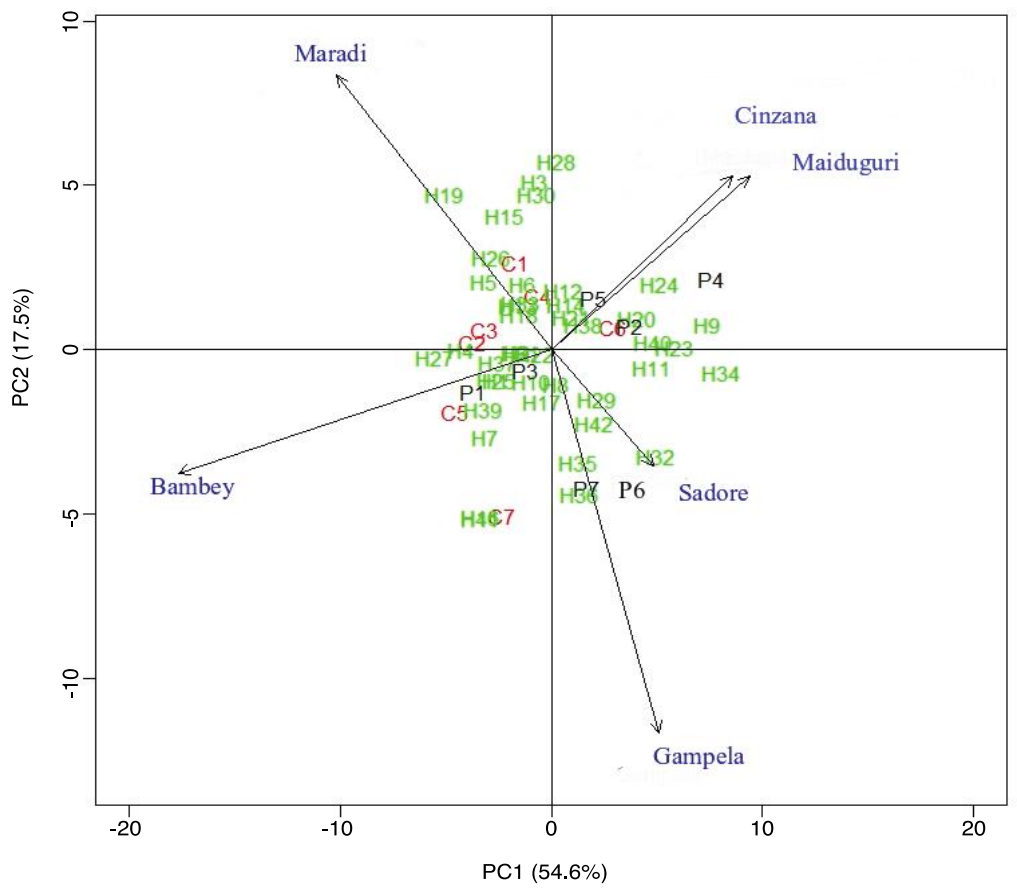

Fig. 4 AMMI 2 biplot of grain yield $\left(\mathrm{g} \mathrm{m}^{-2}\right)$ stability of 42 genotypes ( 7 parents (P, black), their 42 hybrids $(\mathrm{H}$, green) and 7 controls $(\mathrm{C}$, red)) and the relationship between genotypes and experimental sites (blue) evaluated across six environments in West Africa. 


\section{Discussion}

\section{Selection of genotypes based on trait-specific performance}

In this study, we found significant genetic variation for all agro-morphologic traits, except SV and DM\%, among the evaluated WA pearl millet genotypes. This variation could be used effectively for the trait specific selection of genotypes. Sadoré exhibited the lowest average GY among all the test environments. This could be the result of deficient rainfall and high temperature in the growing season because Sadoré received $28 \%$ less rainfall than Gampela, the best yielding environment. The low precipitation in September and October in Sadoré led to post-flowering drought stress, which affects the grain filling and results in lower GY (Yadav 2008). The genotypes that performed well in Sadoré can therefore be used to develop drought tolerant hybrids. Despite receiving the highest amount of rainfall, Maiduguri showed a medium average GY compared to the high yielding environments Gampela and Bambey. High precipitation promotes downy mildew infestation, which explains the occurrence of the higher magnitude of average DM \% in Maiduguri (Supplemental Table 3). Hybrids that showed both high GY and disease resistance in Maiduguri can be used in downy mildew resistance breeding. However, downy mildew resistance highly depends on $\mathrm{G} \times \mathrm{E}$ interactions (Kountche et al. 2013). Therefore, resistant genotypes found in Maiduguri have to be tested in multiple locations to confirm their resistance. Heavy rainfalls, as recorded in Maiduguri, can hamper pollination by washing away the pollen during flowering time resulting in a reduced seed setting and lower GY (Mar et al. 2018; Sattler et al. 2018). Early flowering genotypes have a higher chance to escape terminal drought stress and perform better in environments with marginal rainfall. Early flowering genotypes like PE03942, PE02987 and ICMV IS 92222 could be subjected to further selection for developing early to extra early maturity varieties. The positive relationship of GY with PL indicates that selection of plants with longer PL will increase yield (Bidinger and Raju 2000; Ezeaku et al. 2015; Drabo et al. 2018). Additionally, PL plays an important role when it comes to variety acceptance by Sahelian farmers (Ouendeba 1993). For example, Nigerien farmers prefer long panicles, while Malian Farmers prefer the short type. GY had a significant positive correlation with PH, which is directly related to STW. It is therefore possible to select for GY and fodder yield (Upadhyaya et al. 2018). However, the continuous selection of these tall genotypes will develop taller genetic material (Kenga et al. 2004), which will be more prone to lodging. In general, the selection of traits should be prioritized depending on the preference of farmers and the condition of the agro-ecological target zones. 


\section{The extent of heterosis in pearl millet hybrid breeding in West Africa}

Successful hybrid breeding mainly relies on the magnitude of heterosis for economically important traits in the target region. Presence of heterosis was found in many of the previous studies on pearl millet. The trials that were based on line $\times$ tester designs with inbred parents cannot be compared directly with our results, but showed the potential of pearl millet top-cross hybrids for WA (Bidinger et al. 1994; Bidinger et al. 2005; Kanfany et al. 2018; Mahalakshmi et al. 1992; Yadav et al. 2000). In our study, the PMPH and PBPH level of GY was relatively higher than of the other traits which agrees with several studies on heterosis in pearl millet (Bidinger et al. 2003; Pucher et al. 2016; Yadav et al. 2006). This study with 24\% PMPH and 9\% PBPH on average for GY indicates the possibility of increasing total GY productivity and shows good potential for hybrid breeding in WA (Table 4). A PMPH with 23\% on average was observed by Sattler et al. (2019) in 136 population hybrids. Pucher et al. (2016) observed an average PMPH of $17 \%$ for GY in 100 WA population hybrids. Similarly, $17 \%$ of PMPH was found in 19 hybrids from a cross between 4 Indian landraces and 3 elite populations in African Indian origin by Yadav (2006). Higher prevalence of PBPH is often found in pearl millet. For example, Ouendeba et al (1993) found an average PBPH of $44 \%$ in a study on African landraces carried out in two locations in Niger over two years. In our study, the two best yielding hybrids (1 and 22) exhibited a PBPH of $39.87 \%$ and $18.82 \%$ respectively, showing the potential to increase yield by breeding hybrid varieties. However, farmers can also use the control ICMV IS 89305 as a short-term alternative to the best hybrid population (Kapelga $\times$ ICMV IS 92222) as it yielded only $3 \%$ less than the best population hybrid tested.

Comparing the hybrids to control varieties is necessary to test the yield superiority of the best hybrids over the best commercially available varieties. The best hybrid 22 (Kapelga $\times$ ICMV IS 92222) had a 3\% to $45 \%$ higher GY relative to the seven OPV and landrace control varieties. Moreover, this hybrid showed a 17\% yield superiority over the improved control OPV Souna 3, which is recommended for production in the National catalogs of Senegal and Niger. The low standard heterosis estimates in some hybrids were due to inclusion of the non-adapted parent from Sudan in the data set. The good performance of most control varieties underlines their excellent local adaptation.

We observed the highest amount of PMPH for hybrids in Sadore (69\%), which was significantly positively correlated with the mean GY of hybrids in the respective environment. The extent of PMPH was also significantly positively correlated with the environmental mean of Cinzana, Gampela and Maradi. These are the environments which received low rainfall during the growing season and might have faced a certain amount of drought stress, 
which gives a clear indication of the fact that the population hybrids were highly advantageous under drought environments. A similar trend was observed in a study of 36 pearl millet population hybrids in eight environments in India, where hybrids in drought-prone environments showed the highest average PMPH for GY (Presterl and Weltzien 2003). Haussmann et al. (1998) observed similar results from a study with 24 sorghum (Sorghum bicolor (L.) Moench) parental lines and 12 single-cross hybrids in Kenya. However, the ability of population hybrids to perform well under stress-prone conditions depends on the type and selection procedure of parental genetic material used to produce these hybrids (Pucher et al. 2016).

Besides GY, heterosis was also observed for other important traits. The average PMPH of $-2 \%$ for FLO increases the chance for population hybrids to escape terminal drought stress and perform better in environments with marginal rainfall. All these prior and present studies including ours generally point at the great prospect of pearl millet hybrid breeding in WA and the potential benefits of growing population hybrids for WA smallholder farmers.

\section{Multilocation testing for the identification of stable hybrids}

Farmers in WA often face environmental calamities such as drought stress and irregular rainfall. In our study, the precipitation in Bambey, Gampela, and Maiduguri in 2007 differed noticeably from the average annual rainfall. Therefore, it is necessary to develop stable pearl millet cultivars for GY to cope with such environmental variations. We used AMMI biplots to show the GY stability of the population hybrids and their parents in six different environments. Those environments were clearly separated, which reflects the different levels of precipitation and other environmental stress factors. Population hybrids and their parents showed a similar kind of dispersion in the AMMI biplots, which represents a similar GY stability. The high G×E interaction for GY observed in our study shows the importance of selecting genotypes based on their GY stability. Some genotypes performed well only in one specific environment like Hybrid 19 (Kapelga $\times$ PE02987) in Maradi or Hybrid 27 (ICMV IS $92222 \times$ PE03942) in Bambey. Such site-specific adaptation needs to be validated across years before it can be built on inbreeding programs.

As stated before, the risk-averse smallholder farmers in WA mainly prefer stability with high minimum yield (Haussmann et al. 2012). Such static stability is usually due to population buffering, caused by the heterogeneity within population or landrace varieties (Becker and Lèon 1988). Static stability is often associated with low GY (Fasahat et al. 2016), but hybrid 22 showed both high stability and high GY across all test environments. However, stable hybrids should be chosen based on multiple year trials due to high interannual weather variation. Monitoring 
their performance consistency is essential before releasing those hybrids as commercial varieties in the target environments.

\section{Implications of combining abilities for selection of potential parents}

Our study showed significantly positive GCA effects for GY for several parental OPVs that can be used in future breeding programs. An effective population hybrid breeding program mainly depends on the accurate identification and selection of parental populations, which can be achieved precisely by using GCA effects of the parents rather than using mid-parent values (Gowda et al. 2013, Guo et al. 2013). Therefore, parental population PE02987 and ICMV IS 92222 with significant positive GCA effects are the best candidates for developing high yielding hybrids. GY loss due to drought stress or downy mildew disease is common in many African countries. It is therefore highly beneficial to select populations with drought or downy mildew resistance . Kapelga and PE05344 with a negative GCA for DM\% are useful for further breeding programs to reduce GY losses due to downy mildew. However, these OPVs have to be screened under multiple downy mildew affected environments to validate their disease resistance. $\mathrm{PH}$ is an important trait to the farmers in WA, especially in Senegal and Niger, as they use the stover for fuel or building materials (Ouendeba et al. 1993). However, the Sahel zone of WA is often characterized by strong winds, which causes lodging especially of taller plants (Izge et al. 2007). Therefore, very elastic stems and possibly a medium plant height are required to reduce the lodging risk. Parental OPVs with a negative GCA for PH could be used to produce a hybrid with medium height and reduced lodging.

The magnitude of $\sigma^{2}$ gca was higher than $\sigma_{\text {sca }}^{2}$ for GY and other traits indicating the prevalence of additive gene action in the inheritance of these traits, which agrees with other studies on pearl millet (Kanfany et al. 2018; Ouendeba et al. 1993, Zaveri et al. 1988). This ultimately facilitates the prediction of hybrid performance, because it can be predicted from their parental per se performance. Large GCA: SCA ratios (Baker 1978) and high $H^{2}$ of GY underline the preponderance of additive gene actions. A high correlation between GCA: SCA ratio and $H^{2}$ indicating that additive gene actions largely control highly heritable traits was also observed by Pucher et al. (2016) in their study on WA population hybrids. It must be underlined here that the lack of adaptation of the parental population from Sudan (IP8679) largely contributed to the predominance of additive effects in the present germplasm set. 


\section{Identification of heterotic patterns and prediction of hybrid performance}

We observed significant negative associations between PMPH of GY and geographic distances of parental populations' origins. Crosses between two distant parental populations may cause outbreeding depression due to the loss of co-adapted gene complexes and thus restricts the favorable gene flow from one population to another, ultimately leading to a lower GY and heterosis of hybrids (Raabova' et al. 2008). In our study, the negative correlation between PMPH and geographic distance primarily reflects the poor performance of the Sudanese parental OPV and its offspring.

Developing heterotic groups based on combining ability patterns are essential for pearl millet hybrid breeding, as comprehensively described by Sattler and Haussmann (2020). In our study, crosses between parental materials from Senegal and Mali or Burkina Faso and Niger produced some outstanding hybrids. Potential parental materials from these countries could be separated and crossed systematically via reciprocal recurrent selection to form heterotic groups (Pucher et al. 2016, Sattler and Haussmann 2020). Our study also showed that non-adapted hybrid parents from Sudan should not be considered in a pearl millet hybrid breeding program targeting WA, as their non-adaptation largely reduced hybrid performance in WA.

\section{Conclusions}

The present study was meant to complement other existing combining ability studies in Sahelian pearl millets. It generally confirmed the potential benefits of hybrid breeding and exploitation of heterosis to improve pearl millet production in WA. Crosses of populations from Senegal and Mali or Burkina Faso and Niger produced high yielding hybrids. Incorporating genetic materials from these countries to establish heterotic pools based on combining ability is a promising approach. The best genotype in the present study, hybrid 22 (Kapelga $\times$ ICMV IS 92222) with 47\% and 19\% PMPH and PBPH for GY, and outstanding yield stability across all six test environments, seems potentially very suitable for farmers in the WA region. However, data from multiple years are necessary to underpin our findings and to confirm the observed yield stability. Our study also showed that preselection of hybrid parents for adaptation to the target environment is key - and that inclusion of too distant or non-adapted parents (for example from Sudan) in the crossing work might not be effective in a breeding program targeting WA. 


\section{Acknowledgments}

The authors are grateful to the German Ministry for Economic Cooperation and Development (BMZ) for financial support to the field research presented here (GIZ project numbers 05.7860.9-001.00 and 13.1432.7001.00); and to the McKnight Foundation Collaborative Crop Research Program for the discretionary research funds provided to B.I.G. Haussmann. This publication was finalized as part of the CGIAR Research Program on Dryland Cereals.

\section{Declarations}

Conflicts of interest The authors have no conflict of interest

Ethics approval This experiment did not include animals/human and proper ethical standards were maintained 


\section{References}

Baker RJ (1978) Issues in diallel analysis. Crop Sci 18:533-536.

Bashir EM (2015) Genetic and agro-morphological diversity and genotype by environment interaction of yield and nutritional quality traits in pearl millet germplasm from Sudan. Cuvillier Verlag, Inhaberin Annette Jentzsch-Cuvillier, Nonnenstieg 8, 37075 Göttingen, Germany.

Bashir EMA, Ali AM, Ali AM, Ismail MI, Parzies HK, Haussmann BIG (2014) Patterns of pearl millet genotypeby-environment interaction for yield performance and grain iron $(\mathrm{Fe})$ and zinc $(\mathrm{Zn})$ concentrations in Sudan. Field Crop Res 166:82-91.

Becker HC, Leon J (1988) Stability analysis in plant breeding. Plant Breed 101:1-23.

Bidinger FR, Raj AB, Abraha N, Ali AM, Obilana AB, Jones RB (2005) Topcross hybrids as an entry into commercial seed production of pearl millet in Eastern Africa. Exp Agric 41:335-356.

Bidinger FR, Raju DS (2000) Mechanisms of adjustment by different pearl millet plant types to varying plant population densities. J Agric Sci 134:181-189.

Bidinger FR, Sharma MM, Yadav OP (2008) Performance of landraces and hybrids of pearl millet [Pennisetum glaucum (L.) R. Br.] under good management in the arid zone. Indian J Genet Plant Breed 68:145-148

Bidinger FR, Weltzien E, Mahalakshmi RV, Singh SD, Rao KP (1994) Evaluation of landrace topcross hybrids of pearl millet for arid zone environments. Euphytica 76:215-226.

Bidinger FR, Yadav OP, Sharma MM, Van Oosterom EJ, Yadav YP (2003) Exploitation of heterosis for simultaneous improvement in both grain and stover yields of arid zone pearl millet (Pennisetum glaucum (L.) R. Br.). Field Crop Res 83:13-26.

Brunken JN (1977) A systematic study of Pennisetum sect. Pennisetum (Gramineae). Am J Bot 64: 161-176.

Burgarella C, Cubry P, Kane NA, Varshney RK, Mariac C, Liu X, Shi C, Thudi M, Couderc M, Xu X, Chitikineni A (2018) A western Sahara center of domestication inferred from pearl millet genomes. Nat Ecol Evol 2: $1377-1380$

Burton GW (1974) Factors affecting pollen movement and natural crossing in pearl millet. Crop Sci 14:802-805. 
Butler DG, Cullis BR, Gilmour AR, Gogel BJ (2009) ASReml-R Reference Manual. The State of Queensland, Dep. Of Primary Industries and Fisheries, Brisbane.

Christinck BA, Diarra M, Horneber G (2014) Innovations in seed systems: Lessons from the CCRP-funded project -Sustaining farmer-managed seed initiatives in Mali, Niger, and Burkina Faso. p 75.

Dave HR (1986) Pearl millet hybrids. In Proceedings of the international pearl millet workshop. pp 7-11.

De Mendiburu F (2014) Agricolae: statistical procedures for agricultural research. R package version 1(1).

Diack O, Kane NA, Berthouly-Salazar C, Gueye MC, Diop BM, Fofana A, Sy O, Tall H, Zekraoui L, Piquet M, Couderc M (2017) New genetic insights into pearl millet diversity as revealed by characterization of early-and late-flowering landraces from Senegal. Front Plant Sci 8:818.

Drabo I, Zangre RG, Danquah EY, Ofori K, Witcombe JR, Hash CT (2018) Identifying farmers' preferences and constraints to pearl millet production in the Sahel and North-Sudan zones of Burkina Faso. Exp Agric $55: 765-775$

Duvick DN and Cassman KG (1999) Post-green revolution trends in yield potential of temperate maize in the North-Central United States. Crop Sci 39: 1622-1630.

Ezeaku IE, Angarawai II, Aladele SE, Mohammed SG (2015) Correlation, path coefficient analysis and heritability of grain yield components in pearl millet (Pennisetum glaucum (L.) R. Br.) parental lines. J Plant Breed Crop Sci 7:55-60.

FAO (2017) FAO statistical databases. FAO, Rome. http://faostat.fao.org (accessed 19 Feb. 2018).

Farshadfar E (2008) Incorporation of AMMI stability value and grain yield in a single non-parametric index (GSI) in bread wheat. Pak J Biol Sci 11:1791.

Fasahat P, Rajabi A, Rad JM, Derera J (2016) Principles and utilization of combining ability in plant breeding. Biometrics Biostat Int J 4:1-24.

Gemenet DC, Beggi F, Hash CT, Sy O, Sanogo MD, Zangre RG, Falalou H, Buerkert A, Haussmann BIG (2015) Towards understanding the traits contributing to performance of pearl millet open-pollinated varieties in phosphorus-limited environments of West Africa. Plant Soil 407: 243-259. 
Gemenet DC, Leiser WL, Beggi F, Herrmann LH, Vadez V, Rattunde HFW, Weltzien E, Hash CT, Buerkert A, Haussmann BIG (2016) Overcoming Phosphorus Deficiency in West African Pearl Millet and Sorghum Production Systems: Promising Options for Crop Improvement. Front. Plant Sci. 7: 1389.

Gowda M, Zhao Y, Maurer HP, Weissmann EA, Würschum T, Reif JC (2013) Best linear unbiased prediction of triticale hybrid performance. Euphytica 191:223-230.

Griffing BR (1956) Concept of general and specific combining ability in relation to diallel crossing systems. Aust J Biol Sci 9:463-493.

Guo T, Li H, Yan J, Tang J, Li J, Zhang Z, Zhang L, Wang J (2013) Performance prediction of F1 hybrids between recombinant inbred lines derived from two elite maize inbred lines. Theor Appl Genet 126:189-201.

Haussmann BIG, Boureima SS, Kassari IA, Moumouni KH, Boubacar A (2007) Mechanisms of adaptation to climate variability in West African pearl millet landraces-a preliminary assessment. J SAT Agric Res $3: 1-3$.

Haussmann BIG, Obilana AB, Blum A, Ayiecho PO, Schipprack W, Geiger HH (1998) Hybrid performance of sorghum and its relationship to morphological and physiological traits under variable drought stress in Kenya. Plant Breed 117:223-229.

Haussmann BIG, Fred Rattunde H, Weltzien-Rattunde E, Traoré PSC, Vom Brocke K, Parzies HK (2012) Breeding strategies for adaptation of pearl millet and sorghum to climate variability and change in West Africa. J Agron Crop Sci 198:327-339.

Hoekstra FA, Crowe LM, Crowe JH (1989) Differential desiccation sensitivity of corn and Pennisetum pollen linked to their sucrose contents. Plant Cell Environ 12:83-91.

Izge AU, Kadams AM, Gungula DT (2007) Heterosis and inheritance of quantitative characters in a diallel cross of pearl millet (Pennisetum glaucum L.). J Agron 6:278-285

Kanfany G, Fofana A, Tongoona P, Danquah A, Offei S, Danquah E, Cisse N (2018) Estimates of combining ability and heterosis for yield and its related traits in pearl millet inbred lines under downy mildew prevalent areas of Senegal. Int J Agron.

Kelley TG, Rao PP, Rattunde EW, Purohit ML (1996) Adoption of improved cultivars of pearl millet in an arid environment: straw yield and quality considerations in western Rajasthan. Exp Agric 32:161-171. 
Kenga R, Alabi SO, Gupta SC (2004) Combining ability studies in tropical sorghum (Sorghum bicolor (L.) Moench). Field Crop Res 88:251-260.

Kountche BA, Hash CT, Dodo H, Laoualy O, Sanogo MD, Timbeli A, Vigouroux Y, This D, Nijkamp R, Haussmann BIG (2013) Development of a pearl millet Striga-resistant genepool: Response to five cycles of recurrent selection under Striga-infested field conditions in West Africa. Field Crop Res 154:82-90.

Krishnamurthy L, Serraj R, Rai KN, Hash CT, Dakheel AJ (2007) Identification of pearl millet [Pennisetum glaucum (L.) R. Br.] lines tolerant to soil salinity. Euphytica 158:179-188.

Kumara Charyulu D, Bantilan MCS, Rajalaxmi A, Rai KN, Yadav OP, Gupta SK, Singh NP, Shyam DM (2014. Working Paper Series No 52 Patancheru, Telangana, India: International Crops Research Institute for the Semi-Arid Tropics 76.

Lamkey KR, Edwards JW (1999) Quantitative genetics of heterosis. In: Coors JG, Pandey S (eds.) The genetics and exploitation of heterosis in crops. ASA, CSSA, and SSSA, Madison, WI, USA, pp 31-38.

Mahalakshmi V, Bidinger FR, Rao KP, Raju DS (1992) Performance and stability of pearl millet topcross hybrids and their variety pollinators. Crop sci 32:928-932.

Mahmodi N, Yaghotipoor A, Farshadfar E (2011) AMMI stability value and simultaneous estimation of yield and yield stability in bread wheat ('Triticum aestivum L). Aust J Crop Sci 5:1837-1844.

Manning K, Pelling R, Higham T, Schwenniger JL, Fuller DQ (2011) 4500-Year old domesticated pearl millet (Pennisetum glaucum) from the Tilemsi Valley, Mali: new insights into an alternative cereal domestication pathway. J Archaeol Sci 38:312-322.

Mar S, Nomura H, Takahashi Y, Ogata K, Yabe M (2018) Impact of erratic rainfall from climate change on pulse production efficiency in lower Myanmar. Sustainability 10:402.

Mason SC, Maman N, Pale S (2015) Pearl millet production practices in semi-arid West Africa: A review. Exp Agric 51:501-521.

Melchinger AE, Gumber RK (1998) Overview of heterosis and heterotic groups in agronomic crops. In: Larnkey KL, Staub JE (eds) Concepts and breeding of heterotic crop plants. CSSA Spec. Publ. 25, Madison, pp 29-44. 
Ndjeunga, J (1997) Constraints to variety release, seed multiplication, and distribution of sorghum, pearl millet, and groundnut in Western and Central Africa. In Alternative strategies for smallholder seed supply: proceedings of an International Conference on Options for Strengthening National and Regional Seed Systems in Africa and West Asia, Harare, Zimbabwe, 502:34.

Ouendeba B, Ejeta G, Nyquist WE, Hanna WW, Kumar A (1993) Heterosis and combining ability among African pearl millet landraces. Crop Sci 33:735-739.

Pandey P, Pandey VR, Kumar A, Yadav S, Tiwari D, Kumar R (2015) Relationship between heterosis and genetic diversity in Indian pigeonpea [Cajanus cajan (L.) Millspaugh] accessions using multivariate cluster analysis and heterotic grouping. Aust J Crop Sci 9:494-503.

Payne WA, Williams JH, Moussa KA, Stern RD (1998) Crop diversification in the Sahel through use of environmental changes near Faidherbia Albida (Del.) A. Chev. Crop Sci 38:1585-1591.

Piepho HP, Büchse A, Emrich K (2003) A hitchhiker's guide to mixed models for randomized experiments. J Agron Crop Sci 189:310-322.

Ponnaiah G, Gupta SK, Blümmel M, Marappa M, Pichaikannu S, Das RR, Rathore A (2019) Utilization of Molecular Marker Based Genetic Diversity Patterns in Hybrid Parents to Develop Better Forage Quality Multi-Cut Hybrids in Pearl Millet. J Agric 9:97.

Presterl T, Weltzien E (2003) Exploiting heterosis in pearl millet for population breeding in arid environments. Crop Sci 43:767-776.

Pucher A, Sy O, Angarawai II, Gondah J, Zangre R, Ouedraogo M, Sanogo MD, Boureima S, Hash CT, Haussmann BIG (2015) Agro-morphological characterization of West Africa African pearl millet accessions. Crop Sci 55:737-748.

Pucher A, Sy O, Sanogo MD, Angarawai II, Zangre R, Ouedraogo M, Boureima S, Hash CT, Haussmann BIG (2016) Combining ability patterns among West African pearl millet landraces and prospects for pearl millet hybrid breeding. Field Crop Res 195:9-20.

Purchase JL, Hatting H, Van Deventer CS (2000) Genotype $\times$ environment interaction of winter wheat (Triticum aestivum L.) in South Africa: I. AMMI analysis of yield performance. S Afr J Plant Soil 17:95-100. 
R Development Core Team (2018) R: A language and environment for statistical computing. 2.14.2. R Found. Stat. Comput., Vienna.

Raabová J, Muenzbergová Z, Fischer M (2008) Consequences of near and far between-population crosses for offspring fitness in a rare herb. Plant Biol 11:829-836.

Ramya AR, Ahamed M L, Satyavathi CT, Rathore A, Katiyar P, Raj AGB, Kumar S, Gupta R, Mahendrakar MD, Yadav RS, Srivastava RK. (2018) Towards defining heterotic gene pools using SSR markers in pearl millet [Pennisetum glaucum (L.) R. Br.]. Front Plant Sci 8:1934.

Rodríguez F, Alvarado G, Pacheco Á, Crossa J, Burgueño J (2015) AGD-R (Analysis of Genetic Designs with R for Windows) Version 5.0. International Maize and Wheat Improvement Center.

Sattler FT, Haussmann BIG (2020) A unified strategy for West African pearl millet hybrid and heterotic group development. Crop Sci. 60: 1-13.

Sattler FT, Pucher A, Ango IK, Sy O, Ahmadou I, Hash CT, Haussmann BIG (2019) Identification of combining ability patterns for pearl millet hybrid breeding in West Africa. Crop Sci 59:1509-1603.

Sattler FT, Sanogo MD, Ango IK, Angarawai II, Gwadi KW, Dodo H, Haussmann BIG (2018) Characterization of West African accessions from a pearl millet reference collection for agro-morphological traits and Striga resistance. Plant Genet Resour 16:260-272.

Smale M, Diakité L, Keita N (2012) Millet transactions in market fairs, millet diversity and farmer welfare in Mali. Environ Dev Econ 17:523-546.

Stich B, Haussmann BIG, Pasam R, Bhosale S, Hash CT, Melchinger AE, Parzies HK (2010) Patterns of molecular and phenotypic diversity in pearl millet [Pennisetum glaucum (L.) R. Br.] from West Africa Africa and their relation to geographical and environmental parameters. BMC Plant Biol 10:1-10.

Upadhyaya HD, Reddy KN, Pattanashetti SK, Kumar V, Ramachandran S (2018) Identification of promising sources for fodder traits in the world collection of pearl millet at the ICRISAT genebank. Plant Genet Resour 16:127-136. 
van Oosterom EJ, Whitaker ML, Weltzien E (1996) Integrating genotype by environment interaction analysis, characterization of drought patterns, and farmer preferences to identify adaptive plant traits for pearl millet. In: Cooper M, Hammer GL (eds.) Plant adaptation and crop improvement. CABI, Oxford, UK, pp 383-402.

van Staveren JP, Stoop WA (1985) Adaptation to toposequence land types in West Africa of different sorghum genotypes in comparison with local cultivars of sorghum, millet, and maize. Field Crop Res 11:13-35.

Varshney RK, Shi C, Thudi M, Mariac C, Wallace J, Qi P, Zhang H, Zhao Y, Wang X, Rathore A, Srivastava RK, Chitikineni A, Fan G, Bajaj P, Punnuri S, Gupta SK, Wang H, Jiang Y, Couderc M, Katta MAVSK, Paudel DR, Mungra KD, Chen W, Harris-Shultz KR, Garg V, Desai N, Doddamani D, Kane NA, Conner JA, Ghatak A, Chaturvedi P, Subramaniam S, Yadav OP, Berthouly-Salazar C, Hamidou F, Wang J, Liang X, Clotault J, Upadhyaya HD, Cubry P, Rhoné B, Gueye MC, Sunkar R, Dupuy C, Sparvoli F, Cheng S, Mahala RS, Singh B, Yadav RS, Lyons E, Datta SK, Hash CT, Devos KM, Buckler E, Bennetzen JL, Paterson AH, Ozias-Akins P, Grando S, Wang J, Mohapatra T, Weckwerth W, Reif JC, Liu X, Vigoroux Y, Xu X (2017) Pearl millet genome sequence provides a resource to improve agronomic traits in arid environments. Nat Biotechnol 35:969-976.

Weltzien E, Whitaker ML, Rattunde HFW, Dhamotharan M, Anders MM (1998) Participatory approaches in pearl millet breeding. In: Witcombe JR, Virk DS, Farrington (eds.) Seeds of choice: Making the most of new varieties for small farmers. Oxford \& IBH Publ. Co. New Delhi, India, pp 143-170.

Yadav OP (2006) Heterosis in crosses between landraces and elite exotic populations of pearl millet [Pennisetum glaucum (L.) R. Sr.] in arid zone environments. Indian J Genet Plant Breed 66: 308-311.

Yadav OP (2008) Performance of landraces, exotic elite populations and their crosses in pearl millet (Pennisetum glaucum) in drought and non-drought conditions. Plant Breed 127:208-210.

Yadav OP, Rai KN (2013) Genetic Improvement of Pearl Millet in India. Agric Res 2:275-292.

Yadav OP, Weltzien-Rattunde E, Bidinger FR, Mahalakshmi V (2000) Heterosis in landrace-based topcross hybrids of pearl millet across arid environments. Euphytica 112:285-295.

Zaveri PP, Phul PS, Chahal GS (1988) Genetic studies in relation to population improvement in pearl millet. The Indian J Genet Plant Breed 48:175-180. 

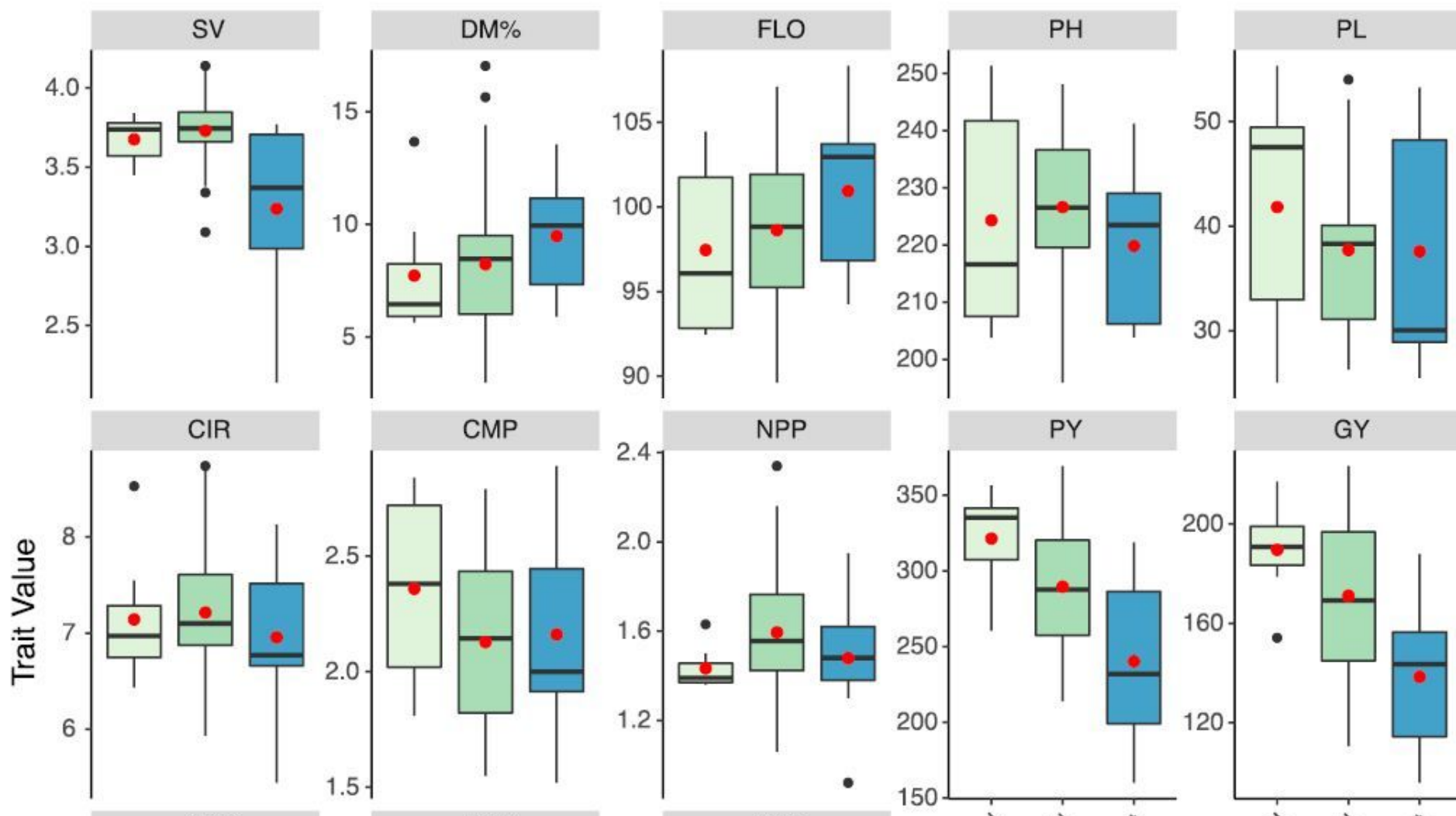

NPP
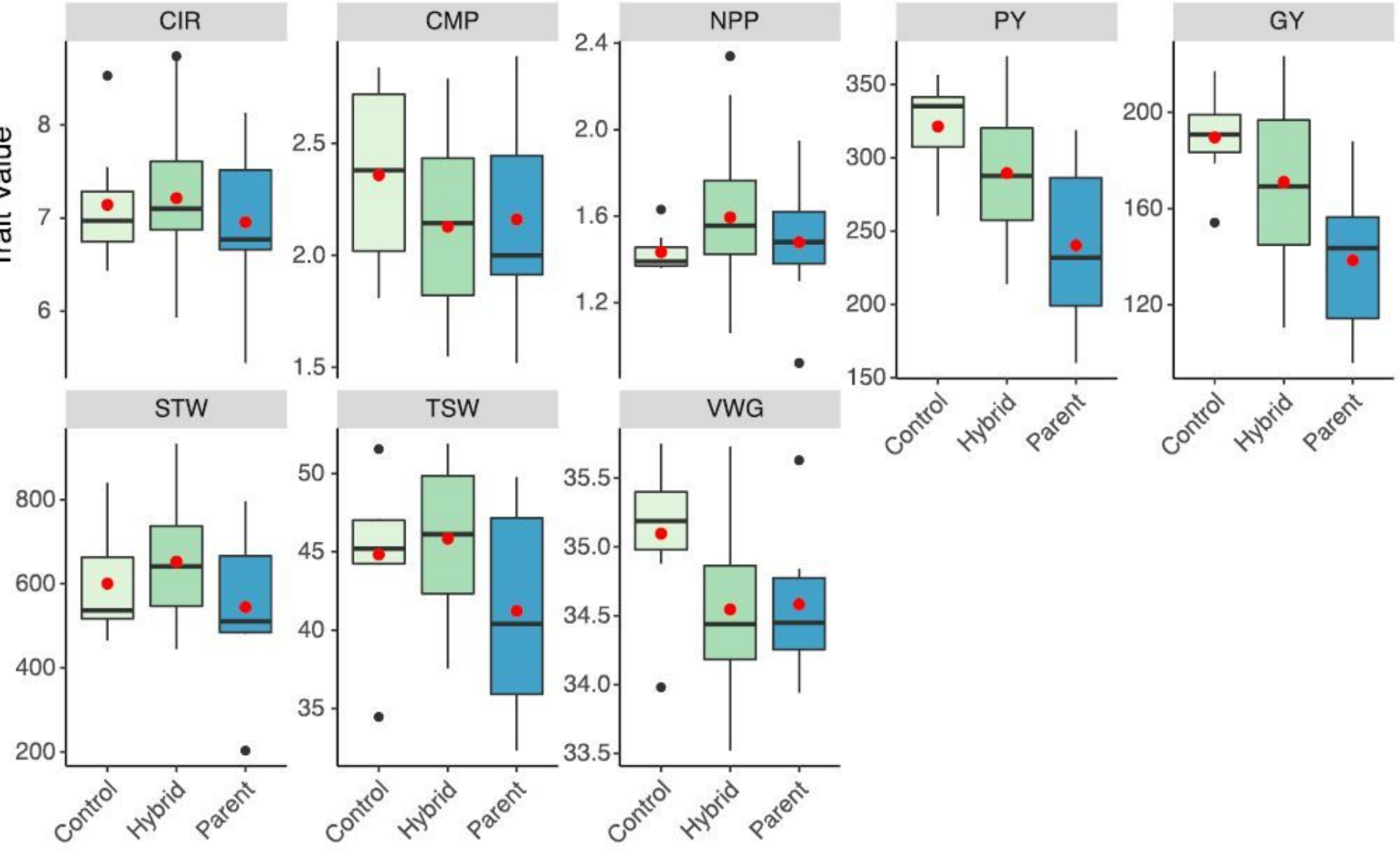

Genotype

\section{Figure 1}

Boxplots with the arithmetic means (red dots) for 13 agronomic traits of 7 parental populations, their 42 offspring and 7 control varieties evaluated across six environments in West Africa. Traits are: SV, seedling vigor; DM\%, percentage of downy mildew infestations; FLO, days to $50 \%$ flowering; PH, plant height; PL, panicle length CIR, panicle circumference, CMP, panicle compactness; NPP, number of panicles per plant; PY, panicle yield; GY, grain yield; STW; dry stover weight;; TSW, thousand seed weight; VWG, volumetric weight of grains. 


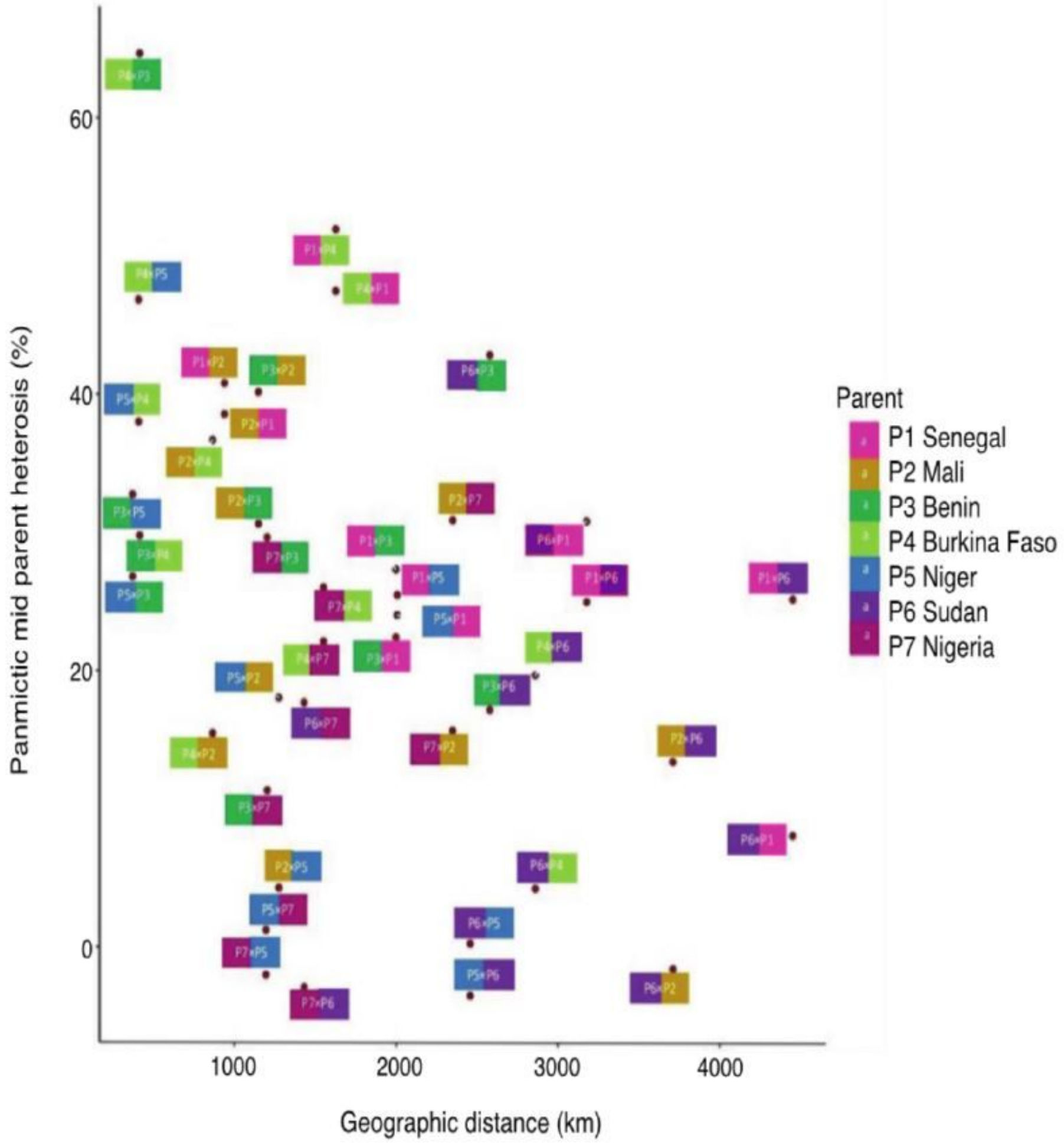

Figure 2

Scatter plot showing relationship between geographic distances $(\mathrm{km})$ of parental populations' origins and panmictic mid parent heterosis for grain yield $(\mathrm{g} \mathrm{m}-2)$ of 42 pearl millet population hybrids evaluated across six environments in West Africa. 


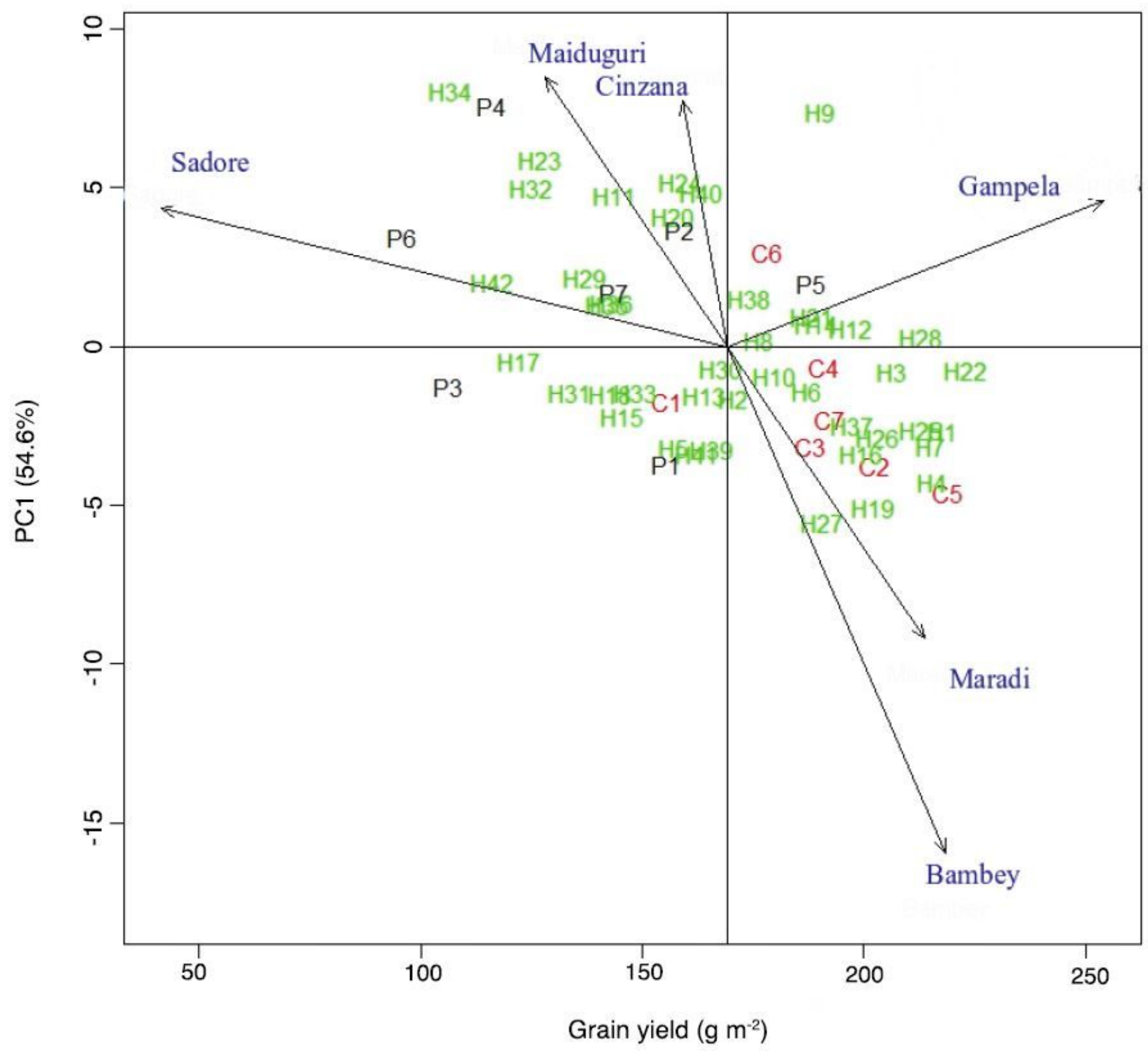

Figure 3

AMMl1 biplot of grain yield ( $\mathrm{g} \mathrm{m}-2)$ vs. PC1 of 42 genotypes (7 parents (P, black), their 42 hybrids $(\mathrm{H}$, green) and 7 controls (C, red)) evaluated across six environments in West Africa. 


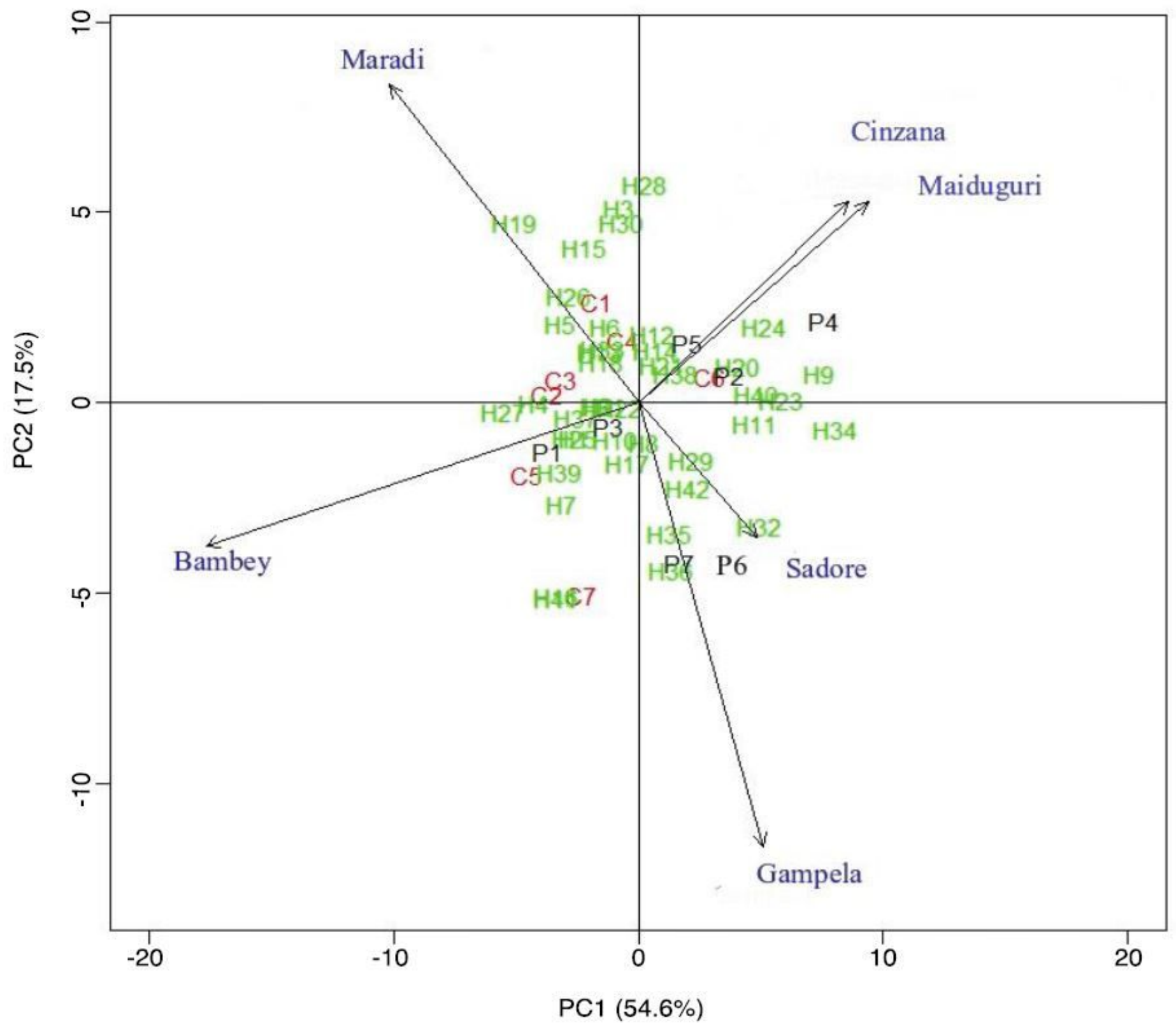

Figure 4

AMMI 2 biplot of grain yield ( $\mathrm{g} \mathrm{m}-2)$ stability of 42 genotypes ( 7 parents $(P$, black), their 42 hybrids $(H$, green) and 7 controls ( $\mathrm{C}$, red)) and the relationship between genotypes and experimental sites (blue) evaluated across six environments in West Africa. 